\title{
Genealogy and Holiness of Seed in Second Temple Judaism: Facts or Creative Supposition?
}

\subsection{Introduction}

Cecilia Wassen states that "Second Temple Judaism was highly concerned with genealogical purity"1 concerning wives' racial origins, deducing this from the forbidden marriages in 4Q269 (4QD ${ }^{d}$ ) 9:2-4 and 4Q397 (4QMMTd) II:12-14, associated in these texts with the rule against כלאים kil'ayim (mixture). To begin with, I do not perceive such a concern over "genealogical purity" with respect to laics, and although Wassen adds that "priests, more than others, had to be careful with regard to the lineage of their spouses," she does not quote any support in her argument that the "high concern" related also to laic Jews. ${ }^{2}$ Further, Wassen's association of these rules with "genealogical purity" is inappropriate, as I shall argue. Indeed, the association of "improper marital matching" with kil'ayim seemed odd to Wassen too, ${ }^{3}$ since she qualified her assumption as a "metaphoric use," but did not attempt to resolve this oddity by discussing the authors' motives for such an association, despite the fact that two different authors of two distinct writings in distinct circumstances indicate the same seemingly odd motive.

The primary purpose of this chapter is to argue against the notion, proposed by some scholars, that Second Temple Judaism, including the Qumran community, extended the existing priestly marriage restrictions to laics; they claim that this modification was indeed established by Ezra's intermarriage prohibition, which they argue was founded on an innovative concept of preserving the Israelite holy seed from intermixing with profane seed, which defiles it.

I shall argue that such a concept was not in the mindset of the Israelite community in all its aspects, and did not induce Ezra's prohibition. I shall contest the evidence cited by these scholars, and propose a different interpretation of the writings of Ezra and Nehemiah on the issue of intermarriage, demonstrating that their concern for the survival of the Israelite people with its particular

1 Wassen, Women, 76-78.

2 For an extended discussion of these marriage restrictions, regarding their character of holiness, see pp. $308-310$.

3 Wassen, Women, 76 .

(C) PAUL HEGER, 2014 | DOI 10.1163/9789004277113_010 
culture among the idolatrous nations surrounding and threatening to overwhelm it induced them to promulgate the intermarriage prohibition. Wassen's kil'ayim rebus will also be resolved.

\subsection{Genealogical Purity or Cultural Survival?}

\subsubsection{The Nature of Restrictions on Marriage in Second Temple Judaism}

Before disputing Wassen's thesis and presenting my own interpretation of the above Qumran writings, I wish to clarify the connotation of the different biblical terms used in connection with the admixture of different elements. In the first instance, I would assert that the concept of "genealogical purity" is not an ancient Israelite principle, and we do not encounter it in Scripture, Qumranic or rabbinic literatures; race is, in my opinion, a modern concept, alien to Israelite history and culture. The marriage restrictions for priests have no association with genealogy; they are imposed on them "because they offer up the food of your God" (Lev 21:8), the same motive for which they are prohibited from shaving their heads, from being polluted by coming in contact with a corpse, and from marrying a divorcée, as decreed in Lev 21:7, circumstances that have nothing in common with a holy genealogy. ${ }^{4}$

Additional restrictions are imposed on the marriage of the High Priest, "for the consecration of the anointing oil of his God is on him" (Lev 21:12). Moreover, the offspring of his prohibited marriage are defiled (v. 15); this consequence introduces a principle that some prohibited marriages have a detrimental effect on their offspring. This generational aftermath, however, has no association with "genealogical purity"; the same effect of polluting his son and debarring him from serving as a priest would occur if the High Priest were

4 The requirement that the priests must be Aaronite was not originally perceived as due to an inherent holiness of this lineage. As Num 18:8-24 emphasizes, God has not granted land to the Aaronites and Levites at its distribution to the other tribes; instead he has given them and their descendants the various tithes and offerings to God, "an everlasting covenant" to "their sons and daughters." They became holy by their function, presenting the offerings to the Lord, and that role imposed on them various restrictions, enumerated in Lev 21. Therefore, only Aaron's descendants could be priests enjoying these privileges, much like the dictum that an Israelite had to be the descendant of a particular tribe to have the right to receive his heritage land, given to the tribe; we see at the Zelophehad narrative in Num 27 and 36 that inheritance cannot pass from one tribe to another. The same principle is applied in the priest's case: he must be the descendants of Aaron in order to enjoy the privileges given to him and his descendants. A priest with blemishes could not serve at the Temple, although he was of Aaronite strain; he could, however, eat holy food, since he has not inherited land. 
to marry a widowed or divorced daughter of a priest, hence a genealogically pure woman. The High Priest must marry a virgin; marriage with any woman who does not fulfill this requirement is forbidden, and would defile their offspring. Moreover, as I shall demonstrate, the race of the woman has no effect on the race/ethnicity of the offspring, which is established exclusively by the father. Ezra invalidated the priestly status and privileges of some returnees, because they could not prove their fathers' ancestry ${ }^{5}$ from Aaron in the "genealogical record of those who have been the first to return," found by Nehemiah (Ezra 2:62; Neh 7:5 and 64). ${ }^{6}$ The same applied to other families, who could not find their records of their fathers, as we read in the antecedent verses Ezra 2:59-6o and Neh 7:61-62: "but they could not tell בית אבתם וזרעם their fathers' houses, and their seed, whether they were of Israel." In both cases the issue was whether they were descendants of priests or Israelite fathers, ${ }^{7}$ not the ethnicity of their mothers; whether their male ancestors married aliens or prohibited Israelite women was not at question, ${ }^{8}$ and the origin of their mothers was not the determinant factor that established their ethnic identity. At that time, as throughout the entire biblical period, the offspring's identity depended on the father, the source of the Israelite seed. ${ }^{9}$ Hence, children born to a foreign woman and an Israelite man were legally of Jewish ethnicity.

The offspring of a sinful, prohibited marriage of two "racially pure" Israelites is a mamzer, ${ }^{10}$ eternally defiled from entering the assembly of the Lord, as is the "racially pure" emasculated man (Deut 23:2-3). The prohibition of the

They were called the sons of Barzillai, the name of their ancestor mother, because their ancestor father was unknown.

$6 \quad$ M. Yeb. 4:13 confirms the existence of such records.

7 All the censuses of the Israelites, starting with that recorded in Num 1:2, mention exclusively men. See more about this topic in Chapter 5, pp. 182-184.

8 We read in m. Qidd. 4:1 (paraphrased): Ten genealogical categories immigrated [to Judah] with Ezra from Babylon. There follows a list of the permitted and prohibited intermarriages among them: Levites, Israelites, defiled, converts and free slaves may intermarry; only priests are restricted and may solely marry Levites and Israelites.

9 Lev 24:10 confirms explicitly that the son's ethnic identity is established by his father's ethnicity; it discerns between בן הישראלית ואיש הישראלי "the son of the Israelite woman and the Israelite" at the narrative about the son of an Egyptian father who cursed God; it is evident that the first is not perceived an Israelite.

10 Scripture does not tell us how the mamzer is engendered; neither do we find this information in Qumran writings, which use the term mainly as a metaphorical portrayal of wicked spirits similar to demons, and as a sobriquet for a congregation of wicked people in 4Q510 (4QShir $\left.{ }^{\mathrm{a}}\right)$ and 4 Q511 (4QShirb). In $m$. Yeb. 4:13 we encounter a dispute between tannaim about it. One asserts that it is the offspring of any prohibited sexual relationship between a physically related couple, and the other limits it only to cases in which 
Moabites and Ammonites to join the assembly of the Lord is not associated with a concept of racial purity; Deut $23: 5^{-7}$ indicates its motive. ${ }^{11}$ Similarly defiled and banned from serving as a priest is the offspring of a priest and a "racially pure" divorcée (Lev 23:15). None of these rules is associated with racial purity.

Moreover, Scripture does not prohibit intermarriage with alien women, because when a Jewish man marries an alien woman, she becomes Jewish; ${ }^{12}$ the exception being the seven nations of Canaan, as per the decree in Deut 7:1-4 which affects both men and women. ${ }^{13}$ This particular prohibition is, however, explicitly justified as an expedient to avoid evil idolatrous influence, as is also evident from the decree to practise social separation; thus, genealogical purity is not a factor in this decree. By contrast with the prohibition on intermarriage with Canaanites in Deut 7, Deut 23:4: "No Ammonite or Moabite or any of their descendants may enter the assembly of the LORD, not even in the tenth generation," does not forbid marriages with the daughters of the nations listed, which one would expect if the passage were concerned with intermarriage. Deut 23 only forbids the absorption of males, who have an everlasting impact on their offspring through their seed, but does not apply to Ammonite or Moabite women who are solely the bearer of their husbands' seed, and become Israelite concurrently with their marriage to Israelite men; this decree thus has no affinity with the specific prohibition of intermarriage in Deut $7 \cdot{ }^{14}$ Consequently, the author of Ruth did not hesitate to assert that Ruth, a Moabite, was the ancestor of King David and his dynasty; ${ }^{15}$ there was nothing illegal in Boaz' marriage

the transgression of the prohibition imposes the Karet punishment; this represents the established halakhah.

11 Whether the indicated rationale represents the real motive is beyond the scope of this enquiry, as is the motive on account of which a common priest cannot marry a divorcee, or the High priest a widow, and how this affects the priest's qualification to serve the Lord's bread.

12 In biblical times, there was no conversion procedure, and all the alien women married to Israelite scriptural characters automatically became Israelites. Conversion procedure is a late institution, like the rabbinic rule that the ethnic identity of children born from intermarriage with aliens follows the mother.

13 This is also the understanding of Shaye Cohen, "From the Bible to the Talmud: The Prohibition of Intermarriage," Hebrew Annual Review 7 (1983) 23-39.

14 See an extended discussion on this specific issue in Paul Heger, "Patrilineal or Matrilineal Genealogy in Israel after Ezra," JSJ 43 (2012) 215-248 at 232-233 and "Unabashedly Reading Desired Outcomes" at 113-118.

15 Scholars who do not acknowledge this difference between the forbidden absorption of males into the Israelite people and the permitted marriage with Moabite and Ammonite 
with Ruth, as the rabbis likewise assert. ${ }^{16}$ Therefore, Scripture records as normal, without any censure, the intermarriages of Israelite heroes with Gentile women: Abraham married Keturah (Gen 25:1), ${ }^{17}$ Judah a Canaanite (Gen 38:2),

women have a hard time reconciling the alleged scriptural prohibition of marriage with the fact that a Moabite was the mother of the revered, perpetual Davidic dynasty. A. Siquans, "Foreignness," among other scholars, argues at 449 that there were two opposing trends or groups in Israel with regard to intermarriage with foreign women, writing that "the book of Ruth is an answer to Ezra's and Nehemiah's politics of demarcation against foreigners and their interpretation of Deuteronomy." Karen S. Winslow, "Mixed Marriages in Torah Narratives," in Mixed Marriages; Intermarriage and Group Identity in the Second Temple Period (ed. Christian Frevel, New York: T \& T Clark International, 2011) 132-149, at 149 perceives contradictions between the pro- and contra-exogamy narratives in Scripture, which she sees as reflecting "conflicts among groups of Jews over exogamy." See also the opinions of: Thomas and Dorothy Thompson, "Some Legal Problems in the Book of Ruth," Vetus Testamentum 18 (Leiden: Brill, 1968) 79-99 at 88, B.A. Levine, "In Praise of the Israelite Mishpaha: Legal Themes in the Book of Ruth" in The Quest for the Kingdom of God: Studies in Honor of G. E. Mendehall (eds. H.B. Huffmon et al.: Winona Lake, IN, 1983) 95-106, Gillis Gerleman, Ruth, Das Hohelied (Neukirchen-Vluyn: Neukirchener Verlag des Erziehungsvereins, 1965), and Jack M. Sasson, Ruth: a new translation with a philological commentary and a formalist-folklorist interpretation (Baltimore, MD: Johns Hopkins University Press, 1979) 232.

16 We read in b. Yeb.76b: עמוני ולא עמונית מואבי ולא מואבית: (paraphrased): The biblical command in Deut 23:4 against the absorption of Ammonites and Moabites into the assembly of the Lord, written in masculine, applies only to Ammonite and Moabite men, not to women. It is true that at times the rabbis devised all kinds of strategies to solve biblical contradictions in a manner inconsistent with modern critical viewpoints, but in this case their solution may be endorsed, in light of the results of my investigation presented above, although they did not apply the same exclusion of females in the case of the prohibition of intermarriage with a mamzera, maintained as valid for both men and women. The commentators of the midrash in b. B. Bat. 91b on 1 Chr 4:22b explain its content, namely that Elimelech's emigration to Moab, and the death of his children were elements of the divine plan to bring Ruth to Judah and be the mother of the Davidic dynasty. Hence, the marriage with Ruth was a propitious act. See Heger, "Patrilineal or Matrilineal" $33^{-} 34$ note 36 on this issue.

17 While Gen 25:1 records explicitly that Abraham took Keturah as a אשה wife, the author of $1 \mathrm{Chr}$ 1:32, composed after Ezra's extension of the prohibition against marrying Canaanites to comprise all foreign women, calls her "concubine," which the Chronicles author assumed were excluded from Ezra's prohibition: it is not the only anachronism in Scripture.Jub. 19:11 records that Abraham married "Keturah, from among the daughters of his household servants, for Hagar had died before Sarah." I assume that he attempted to justify Abraham's marriage to a foreign woman, instead of taking Hagar, his previous concubine. Indeed, Gen. R. parsha 61/4, probably concerned by the same question, states that 
Joseph an Egyptian (Gen 41:45), ${ }^{18}$ Moses a Midianite (Exod 2:21) and a Cushite (Num 12:1):19 King David married Maachah, the daughter of King Talmai, king of Geshur (2 Sam 3:3), ${ }^{20}$ and Solomon wed Pharaoh's daughter, a fact recorded without any trace of critique, but rather related to indicate the prominent status in the region accruing to Solomon by marrying into the Egyptian Royal family (1 Kings 3:1); ${ }^{21}$ Zipporah, Moses' Midianite wife, even fulfilled the precept of circumcising their son (Exod 4:25), a command plausibly applicable to Israelites alone. ${ }^{22}$

In addition to these particular notable marriages with alien women, I think we should also count David's marriage with Bathsheba as decisive evidence for the proposition that intermarriages with aliens were not censured. 2 Sam 11:3 records that David did not know initially who she was and "sent someone to find out about her;" he was informed that she was "the wife of Uriah the Hittite." Scripture does not tell us whether she was a Hittite herself or an Israelite

Keturah was indeed Hagar. We observe again how one cannot reliably deduce halakhot or doctrinal thinking from midrashim.

18 A midrash in Mass. Soferim Supplement 1, Chapter 1, hal. 5 asserts that Asenath was really Dinah's daughter born from her sexual encounter with Shechem.

19 A midrash in Sifre piska 99 asserts that this actually refers to Zipporah, his first wife.

20 The rabbis were indeed aware that she was an alien, and $b$. Sanh. 107a justifies this, arguing that she was a Captive Woman, whom the Torah permitted to be taken in marriage.

21 Intermarriages between dynasties inevitably had a political background, and Egypt was the dominant power in the region at that period. In fact, in 1 Kgs 11:1, the introduction to Solomon's stumbling because of being led astray by his many alien wives, Pharaoh's daughter is the only one brought into prominence by citing her separately among his many anonymous wives.

In fact, Scripture does not specify that only an Israelite may accomplish this command, since the first instruction in Gen 17:10 is written in a passive voice, המול "shall be circumcised," and the subsequent direct active command in v. 11 appears in plural mode, ונמלתם "and you should circumcise," without any specific indication of who must accomplish it. However, reason would dictate that an Israelite must fulfill such a crucial precept, and indeed we encounter a dispute about it in b. Abod. Zar. 27a+b and in b. Men. 42a. A halakhah was established to the effect that a Gentile may not perform circumcision, but an Israelite woman may do it (Mishne Torah, Hil. Milah 2:1), though it is preferable for it to be performed by an Israelite male. It therefore seems odd that Gwynn Kesssler, "Let's Cross that Body When We Get to It: Gender and Ethnicity in Rabbinic Literature," JAAR, Vol. 73/2 (2005) 329-359 at 333 states that Moses' wife Zipporah "is an outsider, a non-Israelite" who "seems to hover between inside and outside." The circumcision of her son seems to indicate her "insider" status. M. Qidd. 1:7 states that circumcision is one of the precepts obligatory for men, not for women, namely that a man transgresses the Law if he fails to circumcise his son, but a woman does not; it implicitly confirms that a circumcision performed by a woman is valid. 
woman who had married a Hittite. ${ }^{23}$ In either case this event would serve as evidence for the legitimacy of intermarriages at that time in Israelite history, and it is recorded in Scripture without any disapproval based on Bathsheba's Hittite identity. ${ }^{24}$ Ruth the Moabite, Bathsheba, and the Canaanite Tamar are the mothers of the revered Davidic dynasty. 25 "Genealogical purity" was not a component of Israelite law and ideology; indeed, it was an unknown concept.

\subsubsection{The Basis of the Qumranic Marriage Rules of $4 Q_{271}$ and $4 Q_{396}$}

I shall now return to the first topic of our investigation, namely Wassen's linkage of genealogical purity to the kil'ayim prohibition. The two Qumranic rules about marriage associated with Kil'ayim, perceived by Wassen as being associated with the issue of genealogical purity, are built on a quite different principle: they rely on the logical extension of the biblical kil'ayim rules, which have no association whatsoever with genealogical purity. Each of the two rules relates to a different case and cites a different biblical decree. 4Q271 (4QD) III:9-10: "[Moreover, he should not give her to one unfit for her, for] [that is kil'ayim, (ploughing with) o]x and ass and wearing wool and linen together,"26 quotes the biblical rule against kil'ayim from Deut 22:10-11, omitting v. 9, not to plant seeds in the vineyard, although the term kil'ayim appears in that verse, whereas the rule of 4Q396 (4QMMTc) IV:4-11 against intermarriage of priests with Israelites, "[be] cause they are holy. But the sons of Aaron are the ho[liest of the holy]" cites the

23 The marriage of an Israelite woman to an alien man would be perceived in the Second Temple period as a much greater evil that the marriage of an Israelite man to an alien woman; see p. 339 and n. 118 on this issue.

24 The traditional commentators attempt to absolve David from the transgression of intermarriage, alleging that Bathsheba was an Israelite, being the daughter of Eliam and Ahithophel's granddaughter, as recounted among David's Mighty Men in 2 Sam 23:34, and Uriah converted to Judaism or was initially an Israelite, only called the Hittite because he lived among them. These strained solutions indicate the problematic nature of adjusting ancient customs to later rules.

25 In its disapproval of Solomon regarding his marriage with foreign women, 1 Kgs 11:1b-2 bundles together an array of nations, among them Moabites and Ammonites as the peoples with whom God prohibited marriage. This pronouncement cannot serve as evidence against my thesis that Deut 23:4 does not prohibit marrying an Ammonite or Moabite woman. 1 Kgs indicates explicitly the motive of its criticism "because they will surely turn your hearts after their gods," alluding to the prohibition of intermarriage with the Canaanites (Deut 7:3-4), whereas the prohibition to incorporate Ammonites and Moabites is justified by utterly different motives. Therefore, $1 \mathrm{Kgs}$ bundles together nations who are not mentioned anywhere regarding a marriage prohibition, such as the Sidonians, since they are all potential agents of apostasy. 
biblical rule of Lev 19:19: "Do not mate different kinds of animals. Do not plant your field with two kinds of seed. Do not wear clothing woven of two kinds of material." I would argue that these different citations and the omission of Deut 22:9 are not accidental; rather, they offer us a clue to the distinction between the philosophical and legal bases of the two rules.

$4 Q_{271}$ constitutes a recommendation for the father to avoid giving his daughter in marriage to someone unfit for her, ${ }^{27}$ thus avoiding the suffering arising from an ill-suited union. ${ }^{28}$ Its author substantiates his ordinance by quoting the relevant verses Deut 22:10 and 11 that refer to a similar type of kil'ayim, namely the prohibition against working with two animals of differing physical capacities yoked together. Although Scripture does not divulge the motive of this decree, logic indicates it to be a mandate against causing animals to suffer; ${ }^{29}$ we can only speculate, however, on the motive for the prohibited use of linen with wool cloth. ${ }^{30}$ Further, the transgression of these rules has no association with offspring, whereas planting seeds in the vineyard, mentioned in Deut 22:9, has a detrimental effect on the outcome; the produce must be destroyed..$^{31}$ Therefore, the author of $4 \mathrm{Q} 271$ chose not to cite v. 9, since it is not commensurate with the recommendation not to give a daughter to one unfit for her. While such a marriage will bring her personal misery, like the yoking together of two different animals, any offspring are not affected.

The prohibition in $4 \mathrm{Q}_{396} \mathrm{IV}: 4-11$ of intermarriage between priests and Israelites, however, is compared to the mating of two distinct species of animals and sowing two different species of plants, prohibited as כלאים in

27 Since no legal sanctions or consequences are indicated, it is probably safe to assume that the suggestion against marrying an unsuitable woman constitutes advice rather than a strict prohibition.

28 See an extensive study regarding these two Qumranic rules and particularly the legal differences between them in Heger, "Qumranic marriage prohibitions." Remarkably, b. Sanh. 76a decrees a similar recommendation to avoid giving one's daughter to a man unsuitable for her, for example to an old man, but support it with a suitable interpretation of Lev 19:29.

29 TS 11 Q19 (11QTemple $\left.{ }^{a}\right)$ LII:12-13 bundles together two rules that appear in Scripture in different locations, since both are motivated by the same aim to avoid the suffering of animals: "And you shall not muzzle an ox when it treads out the grain (Deut 25:4), and "you shall not plough with an ox and an ass together" (Deut 22:10).

3o Maimonides and other traditional commentators attempted to proffer motives for this odd rule.

31 The biblical text is undefined and is usually interpreted as he will be deprived of it. M. Sheqal. 1:1-2 decrees destruction. 
Lev 19:19. This comparison is the outcome of a logical consideration "[be] cause they are holy. But the sons of Aaron are the ho[liest of the holy]." Holy (all Israelites) and the holiest of the holy (the priests) represent two distinct cosmological categories, such as those implied by innate differences between the various species of animals and plants. Therefore, intermarriage between the two is forbidden, for the same reason as breeding animals of two distinct species or planting two different kinds of plants together: these are actions that have an effect on future offspring, since they change the type of animal or fruit from their original breed as created by God. Similarly, the prohibited mating of priests and Israelites, two different "species," has the effect of defiling their offspring. The child of a priest with an Israelite woman is defiled and cannot serve in the Temple according to Qumran law ומטמאי [ם ["את זרע [ הקודש "and defile the [holy] seed" (4Q396 IV:10), just as the child of a priest with a divorcée,${ }^{32}$ or of the High Priest and a widow, is חלל "defiled," as in Lev 21:15. ${ }^{33}$

In conclusion, the comparison made by the two Qumranic laws on intermarriage with the prohibitions of kil'ayim are not "metaphoric," but the result of logical considerations on the part of the authors, having no association with "genealogical purity" as Wassen claims. The rabbis, who do not accept the Qumranic doctrine of the "most holy" status of the priests, since Scripture calls them holy in Lev 21:6 and identical to all Israelites in Lev 20:6, explicitly deny the Qumranic halakhah in b. Sanh. $76 \mathrm{a}^{34}$ that circumstance explains also the recording of this rule in the polemical $4 \mathrm{Q} 396$. Since we have seen that this modern concept of racial purity does not appear in Scripture or in Qumran decrees and narratives, we may now consider the philosophical and legal basis of Ezra's extension of the specific biblical intermarriage prohibition to all aliens from a more historically authentic perspective.

32 Although Lev 21:15 only defiles the son of a High Priest with an illegitimate partner, $b$. Yeb. 6oa likewise extends the rule to include the offspring of a simple priest and an illegitimate partner, like a divorcée or a prostitute.

33 Using the term טמא the author of $4 \mathrm{Q} 396$ is not careful in discerning between the bibli-

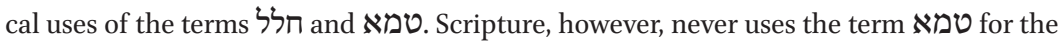
defilement of the priest's offspring.

34 See Heger, "Qumranic Marriage Prohibitions" at 450 a similar dispute between the Qumranic and rabbinic differentiation between priests and laic Isralites. B. Mak. 20a equalizes the prohibition of shaving the entire head for Israelites, although Lev 21:5 prohibits it only to priests, whereas ${ }_{11 Q 19}\left(11 \mathrm{QTemple}^{\mathrm{a}}\right.$ ) XLVIII:7-8 prohibits Israelites only the shaving of the forehead as written in Deut 14:1. 


\subsection{Interpreting Ezra and Nehemiah on Intermarriage}

\subsubsection{The Relevant Texts and Their Main Meaning}

Let us begin by quoting the most relevant selections from the texts of Ezra and Nehemiah:

After these things had been done, leaders came to me and said, "The people of Israel, including the priests and the Levites,35 לא נבדלו have not kept themselves separate from the neighbouring peoples with their detestable practices, like those of the Canaanites, Hittites, Perizzites, Jebusites, Ammonites, Moabites, Egyptians and Amorites. They have taken some of their daughters as wives for themselves and their sons, and have mingled the זרע הקדש holy people (literally seed) with the peoples around them. And the leaders and officials have led the way in this unfaithfulness." (Ezra 9:1-2)

Ezra 9:14 criticizes intermarriage with עמי התעבות האלה "the peoples who commit such detestable practices," and 10:11b exhorts the Jews והבדלו מעמי הארץ ומש ומש "to separate from the peoples around you and from your foreign wives."

Neh 10:29b records the Covenant made with וכל הנבדל מעמי הארצות "all who separated themselves from the neighbouring peoples."

Finally, Neh 13:23-25, 26b states another motive against intermarriage: ואינם they [the sons of the foreign women] do not know how to speak the language of Judah."

35 I dispute Daniel L. Smith-Christopher's theory in "The Mixed Marriage Crisis in Ezra 9-10 and Nehemiah 13: A Study of the Sociology of the Post-Exilic Judean Community," in Second Temple Studies 2 (ed. Tamara C. Eskenazi and Kent Richards. Sheffield: Journal for Studies of the Old Testament (JSOT) Press, 1994) 243-265, at 255 that the mention of the priests and Levites in 9:1 emphasizes the primary sins "of the priests and Levites," because they "are listed first among the guilty." The MT, the LXX, the Leningrad Ms published by the Biblia Hebraica Stuttgartensia and the KJV all list the Israelites first, followed by the priests and Levites. I similarly dispute George W.E. Nickelsburg's interpretation in 1 Enoch 1: A Commentary on the Book of 1 Enoch, Chapter 1-36: 81-108 (Minneapolis, MN: Fortress Press, 2001) at 231 of Ezra 9:1: "that many of the Israelites, but notably a significant number of priests and Levites, have married foreign women, an allegation that has no basis in the scriptural text;" the scriptural text does not in any way indicate whether there were few or many priests among the Israelites who intermarried. The significance of the leaders, however, in terms of having been a bad example is explicitly emphasized in v. 2: "And the leaders and officials have led the way in this unfaithfulness." 
The scope of a narrative is indicated by its introduction, and of an agreement or a law by its preamble, and this is exactly what Ezra 9:1 reveals: The people of Israel, of all its classes, priests, Levites, leaders, and officials (Ezra 9:2) "have not kept themselves separate from the neighbouring peoples," as they should have done. The scale of the sinful intermingling indicates its gravity. The essential theme of the narrative is the absolute necessity of separation from the neighbouring peoples. The Hebrew term בדל "to separate" appears continually as the core of the issue, in the account of the evil circumstances and in the issue's resolution. The text of Ezra 6:21, 9:1, 10:11 and 16; Neh 9:2, 10:29 and 13:3 demonstrates that Ezra's goal of reestablishing the division between the Jews and the others induced his decision to act forcefully and drastically in reestablishing this division. ${ }^{36}$ Then follows the rationale for the required and decreed separation: because of their "detestable practices," as decreed in Deut $7: 1-4 \cdot{ }^{37}$

\subsubsection{Ezra and Nehemiah's Motivation in Extending Prohibition of Intermarriage}

Ezra and Nehemiah extended the prohibition of intermarriage to all foreign women (Ezra 9 and 10 and Neh 13:23-28), but their innovative rule was founded on cultural concerns, ${ }^{38}$ not on their quest for the preservation of the "material" genealogical purity of the holy seed, as some scholars contend. ${ }^{39}$ They interpret

36 Willa M. Johnson, The Holy Seed has been Defiled: The Interethnic Marriage Dilemma in Ezra 9-10 (Sheffield: Sheffield Phoenix Press, 2011), 87 writes: "The overall need to create a functional, collective social identity drove Ezra to summon the people and issue an edict." At 79 she writes that by creating communal boundaries "the community leaders were able to better establish and differentiate between the insiders and outsiders."

37 Ralf Rothenbusch, "The Question of Mixed Marriages between the Poles of Diaspora and Homeland: Observations in Ezra-Nehemiah," Mixed Marriages, 6o-77, at 71 writes: "the rationale for the prohibition of mixed marriages in Ezra 9: 11a 12c-f, B+B', as a whole quite clearly points to the Deuteronomic/Deuteronomistic literature." The Moabites and Ammonites and Egyptians are not included in Deut 7 and in the motive for their exclusion from the assembly of the Lord, but it seems that since Ezra extended the intermarriage prohibition to all foreign women on account of their potential evil influence, he bundled them together as performing abominable practices to justify their inclusion in the prohibition.

38 Armin Lange, "Mixed Marriages and the Hellenistic Religious Reforms," Mixed Marriages, 205-219, at 219 similarly perceives Jubilees' severe criticism of intermarriage, which became "one of the most serious threats against the cultic and religious identity and integrity of Judaism." See our interpretation of Jub. 30:7-12, on this issue in section 8.4.6 of this chapter, pp. $335^{-} 340$.

39 Christine E. Hayes, "Intermarriage and Impurity in Ancient Jewish Sources," HTR 92, 1 (1999) 3-36 and Gentile Impurities and Jewish Identities: Intermarriage and Conversion 
the phrase זרע הקדש, which appears in the announcement of the leaders to Ezra (9:1), as the decisive essence of the sin of intermarriage that had taken place. While other scholarly propositions on this issue will be discussed in the course of my argument against the "holy seed" theory, my primary focus will be on Hayes' writings, since they are the most elaborate on this issue. I will first present my interpretation of the relevant texts in Ezra and Nehemiah and then present grounds for refuting her theory.

Ezra and Nehemiah's extension of biblical intermarriage restrictions with the Canaanites to all Gentiles was motivated by the precarious situation of the small Jewish community of returnees as a people with a distinct culture in the midst of a multitude of idolatrous peoples and partly apostatized non-exiled Jews. This prohibition of intermarriage was intended to ensure the survival of the Jewish people and its particular culture and way of life in these new conditions. Intermarriage tends to lead to lively social interaction with the woman's family, customs and culture, creating the potential of adopting alien ways of life and thus eroding one's own. ${ }^{40}$

The separation of Israel from all other nations appears in the Pentateuch in implicit and explicit expressions. The concept of being chosen from all nations of the world (Deut $7: 6$ ), often reiterated ${ }^{41}$ to underline its significance, suggests Israel's exclusivity and is reinforced by manifold commands to behave differently than other peoples (Deut 7:6), creating a hermetic social boundary between Israel and the nations. The result is the explicit description "I see a people who live apart and do not consider themselves one of the nations" (Num 23:9). The conditions in Judah after the return from Babylon were quite different than before the Exodus. At that earlier period the Jews were the overwhelming majority of the inhabitants, and the few alien residents were compelled by law to accomplish many biblical rules, ${ }^{42}$ particularly those with public character, such as observing the Sabbath (Exod 20:9), the Day of

from the Bible to the Talmud (Oxford: Oxford University Press, 2002) 28-33 and 68-91, and Michael L. Satlow, Jewish Marriage in Antiquity (Princeton, NJ: Princeton University Press, 2001) 136-141.

40 F. Charles Fensham, The Books of Ezra and Nehemiah (Grand Rapids, MI: Eerdmans, 1982), 124 writes: "The reason for this attitude [of Ezra] had nothing to do with racism, but with concern for the purity of the religion of the Lord" and "the influence of a foreign mother, with her connection to another religion, on her children would ruin the pure religion of the Lord and would create a syncretism."

41 See for example Deut 10:15.

42 For example, the prohibition of blood consumption (Lev 17:40), sexual transgressions (Lev 18:26), the rule of the blasphemer (Lev 24:16), various matters of civil laws (Lev 24:22) and their participation in the teaching of the basic Torah laws at the seven yearly meetings (Deut 31:12). 
Atonement (Lev 16:29) and the Passover restrictions (Exod 12:1), and avoiding idol worship (Lev 20:2). In such circumstances, alien women who married into the prevailing Jewish culture had no influential impact on it. Both the alien residents and the alien wives adapted to Israelite customs and rules. Ezra and Nehemiah came to the conclusion that the changed circumstances called for changed laws, and that a sharp, impenetrable separation, leading to the total isolation of the small Jewish community, was the only effective method of ensuring the continuance of the Jewish people and their particular faith. The extension of the intermarriage prohibition to all foreign women is the result of that consideration.

\subsubsection{Ethnicity and Intermarriage}

Sections 8.3.1 and 8.3.2 illustrate my understanding of the relevant texts of Ezra and Nehemiah on the issue of intermarriage, based on careful consideration of the topics associated with the significance and pre-eminence of the principle of Israelite separation, which runs like a red thread through the entire history of Israel from its conception (Gen 17:7-8). It is remarkable to note that two female scholars, working in different historical contexts and with different backgrounds and agendas, reached identical conclusions to mine regarding the Ezra-Nehemiah prohibition of intermarriage in two recently published books. Katherine Southwood asserts that their concern was the preservation of Israelite identity, endangered by the circumstances of "migration and, especially, return immigration." ${ }^{43}$ In her introduction she writes: "Ezra's intermarriage crisis is laden with implications of ethnic differentiation." 44 She states further that "Purity terminology and ideologies are applied to those supposedly not included within Israel in order to debase them." ${ }^{45}$ In another article, however, as it seems to me, Southwood blurs the distinction somewhat between the concepts of ethnicity and genealogical purity as Ezra's motivation for his intermarriage prohibition. ${ }^{46}$ She writes: "Effectively, Ezra transforms the language of holiness by applying it to ethnicity," a statement that seems to me incompatible with Hayes' theory of racial purity, but a page later, after stressing the broad semantic range of the noun "seed," she claims that "In Ezra the title [holy seed] is... imbued with notions of commonality

43 Katherine E. Southwood, Ethnicity and the Mixed Marriage Crisis in Ezra 9-10: An Anthropological Approach (Oxford: Oxford University Press, 2012), 213.

44 Ibid., 2.

45 Ibid., 3 .

46 Katherine E. Southwood, “An Ethnic Affair? Ezra's Intermarriage Crisis against a Context of 'Self Ascription' and 'Description of Others,'” Mixed Marriages 46-59, 56-57. 
or, as Hayes puts it, 'genealogical purity,' " an assertion seeming to contradict her previous statement. Willa Johnson goes a considerable step further, asserting that "Western culture has strongly influenced the development of biblical interpretation. As an African-American woman born in a culture invested for centuries in the slavery of Africans and which utilized Ezra 9-10 as a racialist and racist argument against interethnic marriage ..."47

She writes further: "The intermarriage dilemma establishes that identity issues and the result of exile rather than rampant racialist or racist concerns motivated the mandate against interethnic marriage." ${ }^{48}$ Both are clearly opposed to the holy seed/race theory, because of these and similar considerations. Southwood builds her theory on the results of her examination of "the relationship between migration and ethnicity, and the dynamics of the association between ethnicity and intermarriage." 49 Johnson states that "in antiquity, if not racial concerns, certainly issues of ethnic difference presented considerable stress for early Jewish communities."50 Many scholars have postulated different motives for Ezra's prohibition of intermarriage and the consequent application of such a drastic measure as breaking up families, some envisaging the preservation of the Jewish religion's purity and the avoidance of syncretism as Ezra's motivation. ${ }^{51}$ I shall not enlarge the scope of the discussion along these lines, however, concentrating instead on disputing the racial/seed

47 Willa M. Johnson, The Holy Seed, 7.

48 Ibid., 15 .

49 Southwood, Ethnicity, 17.

5o Johnson, The Holy Seed, 15 .

51 Sara Japhet, "The Expulsion of the Foreign Women (Ezra 9-10):The Legal Basis, Precedents, and Consequences for the Definition of Jewish Identity," in Sieben Augen auf einem Stein 141-161 does not identify racial or seed purity as Ezra's motive for the expulsion of the foreign women; following her own line of argument, she asserts that the children of a foreign woman, like the children of a slave woman, are affiliated "with their mothers" (148). I dispute her thesis, since Ezra 9:1 explicitly accuses the intermarriage families of not separating from the neighbouring peoples. Further, as we demonstrated Ezra did not recognize as Jews those who did not know their fathers. Hyam Maccoby, "Holiness and purity: the holy people in Leviticus and Ezra-Nehemiah," in Reading Leviticus: a conversation with Mary Douglas (ed. John F.A. Sawyer; Sheffield: Sheffield Academic Press, 1996) 153-170, at 160-163 vigorously disputes some scholars' suggestion that Ezra's action was driven by an exclusivist "racial" ideology. He identifies the alien women expelled by Ezra as elements of the "people of the land," who approached the returnees to build the Temple together, and were rejected by them, as appears in Ezra 4. As recorded in 2 Kgs 17, they were undeniably syncretists, and were regarded by Ezra as idolaters. He realized that if these 'Jews' were permanently accepted by intermarriage, the Jewish monotheism "would have been fatally compromised." 
purity motivation, as proposed by Hayes and others. I do not exclude the possibility that other secondary motivations, such as for example economic interests, particularly land ownership and inheritance, ${ }^{52}$ or marrying up in status for participation in the aristocratic society, ${ }^{53}$ as postulated by some scholars, were also on Ezra's mind, but I do not accept that a racialist aspect, such as purity of seed or blood, was among them. On the basis of my reading of the text and context, without such extraneous considerations as the cruelty of the rule against intermarriage or other suppositions, I believe that the survival of the Jewish people and its particular culture and religion was Ezra's primary motive for his legal provisions.

\subsubsection{The Problematic Concept of "Holy Seed"}

Ezra does not, as it seems, explicitly refer to the similar prohibition in Exod 34:15-16 against socialization and intermarriage with the Canaanites because of their potential evil influence, ${ }^{54}$ since the Exodus prohibition relates only to the marriage of Israelite men with alien women, whereas Ezra wanted to extend the decree of Deuteronomy, which prohibits exogamy in either direction. He did not, however, forget the Exodus rule in considering an extension of the prohibition that explicitly portrayed the consequences of marriage and socialization with foreign peoples, as indeed happened according to Judg 3:6. The prohibition in Exodus follows the sin of the Golden Calf, which God wanted to avoid in future, and the same motive induced Ezra to attempt the separation of the Israelites from the surrounding peoples and their "abominations," often cited in Scripture as referring to idolatry. There is no mention of the preservation of "holy seed" in either source. Moreover, we observe that the intermarriage of foreign women with Israelite men was the situation that enraged and exasperated Ezra, inducing him to such spectacular behaviour as described in Ezra 9:3-5. In contrast, we find Ezra in a more composed state when mentioning in v. 12 the prohibition against giving Jewish women to Gentile men. The contrast indicates his outrage against the misconduct that had occurred and that represented the most dangerous circumstance for the survival of his people, as opposed to his much calmer attitude towards

\footnotetext{
$5^{2}$ See for example Tamara Cohn Eskenazi, "Out from the Shadows: Biblical Women in the Postexilic Era," JSOT 54 (1992) 25-43, at 35 .

53 Smith-Christopher, "The Mixed Marriage Crisis," 261.

54 Shaye J.D. Cohen, "Solomon and the Daughter of Pharaoh: Intermarriage, Conversion, and the Impurity of Women," JANESCU 16-17 (1987) 23-37, at 25 writes: "Judg 3:5-6 confirms the wisdom of the Mosaic prohibition," adding at 26: "Kings argues that Solomon's intermarriage did in fact lead to idolatry."
} 
the potential transgression of Gentile men marrying Jewish women. If the issue of the holy seed were the primary source of Ezra's indignation, one would expect him to reiterate it at this point, since Jewish belief certainly held at this time that it is the man who produces the seed, while the woman merely harbours it. Moreover, Ezra does not mention the phrase זרע הקדש (the foundation of the scholarly concept of race purity) in all his manifold denunciations, exhortations and edicts. Furthermore, at Neh 9:2 where the achievement of his goal, namely the separation from the foreigners, is recorded, the phrase זרע ישראל is specified, indicating the two phrases' correlation in the context of this episode, and the manifest meaning of the phrase זרע הקדש, as discussed below.

The preamble is followed by the details of how the breakdown of the separation occurred, and what its precursors were: "They have taken some of their זרע זרe daughters as wives for themselves and their sons, and have mingled the בעמי הארצות holy people with the around them" (Ezra 9:2a). The phrase זרע הקדש must be interpreted here as "the holy people" rather than as holy seed for a number of reasons. The phrase appears only once here, and elsewhere in Scripture only in Isa 6:13, which has no connection to the concept of the holy seed that must not be mixed with other seed; rather, it has more affinity in that context with the concept of the holy Israelite people who will experience a flourishing renaissance after almost total eradication. ${ }^{55}$ Therefore, we have no comparison to ascertain its meaning from another biblical text, and we must deduce it from the use of the term זרע in biblical literature, from its literary use in Ezra 9:2 and from the context of the intermarriage texts of Ezra and Nehemiah, as argued above.

The term זרע is used for seed in living and plant entities, but also to mean descendants, children or offspring, often in contexts where it must be interpreted in that way. For example, in Gen 3:15 as "offspring/descendants"; 56 in Gen 4:25 as [another] "child"; in Gen 13:16 as "offspring like dust of the earth"; in Gen 15:3 as "children"; 57 in Gen 38:9 as [Onan's] "offspring"; in Gen 46:7 as [Jacob's] "offspring” [to Egypt]; in Gen 48:11 as [Joseph's] "children”; in Lev 18:21 as "children" [to Moloch]; at Lev 22:13, [without] "children"; in Deut 28:46 as [a sign to your] "descendants"; in 1 Sam 2:20: "children" [by this woman]; in

55 The text of Isa 6:13 presents many difficulties of which scholars have attempted to make sense. I prefer the interpretation of Otto Kaiser, Isaiah 1-12: A Commentary (translated from German by R.A. Wilson; Philadelphia: Westminster Press, 1972).

56 Hartley, Genesis at 69 comments on this verse: "There would be enmity between the serpent and the woman, between the offspring of both."

57 Abram possessed seed, but Sarai did not become pregnant; Sarai offered her maid to Abram for procreation (Gen 16:1-2). 
1 Sam 20:42: [witness to your] "descendants"; at 2 Kgs 17:20 as [the rejection of] the "people" [of Israel]; in Isa 1:4 as a "people" [a "brood" of evildoers]; and in Isa 9:19, feeding on the flesh of his own "offspring." More occurrences of the term זרע could be cited that must be interpreted as descendants in its different variants according to the context, ${ }^{58}$ not as seed, and in my opinion the phrase in Ezra 9:2 must be counted as one of them. ${ }^{59}$

Semantically, one cannot mix two quite different elements such as seed and peoples; the literal meaning of the text of Ezra 9:2, translating the term זרע as "seed" would read: "and have mingled the holy seed with the peoples around them," an impossible interpretation. At the next portrayal of the same sinful deed of mingling with the aliens, at 9:14, Ezra describes the details: "to intermarry with the peoples who commit such detestable practices." The separation from the idolatrous peoples is frequently reiterated, indicating the core of the misbehaviour that Ezra is attempting to redress. ${ }^{60}$ The alleged issue of

58 Victor P. Hamilton, Book of Genesis, 198-199 comments on the term זרע and its correct interpretation at the serpent's curse in Gen 3:15, stating: "in a number of passages Heb. zera is a collective referring to distant offspring or a large group of descendants," and cites a substantial list of biblical verses corroborating his assertion.

59 Juha Pakkala, Ezra the Scribe, The Development of Ezra 7-10 and Nehemiah 8, BZAW 347 (Berlin: De Gruyter, 2004) at 109-110 emphasizes that the main motivation "for forbidding mixed marriages in the first place is the religious threat that the other nations pose." He makes a similar assertion emphasizing Ezra's association of his intermarriage prohibition with "Deuteronomistic theology/ideology" in "Intermarriage and Group Identity in the Ezra Tradition (Ezra 7-10 and Nehemiah 8)," Mixed Marriages, 78-88 at 83-84. Regarding the meaning of זרע הקדש, however, he seems to waver in the latter article between on the one hand his assertion that Ezra linked his decree with the deuteronomic motivation, aiming to attain an "inward consolidation of a threatened minority," namely, a social separation, and on the other hand his contemplation that the phrase intends the "holy seed mixes with something that was regarding unclean or impure." I dispute Smith-Christopher's assertion in "The Mixed Marriage Crisis," 256 that Ezra's obsession was the "separation between pure and impure," a qualification that does not appear in the text. Compare Nickelsburg, 1 Enoch 1 who at 231 interprets Ezra 9:1-2 as meaning that the Israelites "have married foreign women and thereby mixed and polluted the holy people," not the seed.

6o James Kugel, "The Holiness of Israel and the Land in Second Temple Times," in Texts, Temples, and Traditions: A Tribute to Menahem Haran (eds. Michael V. Fox et al.; Winona Lake, IN: Eisenbrauns, 1996) 21-32, at 22-24 states that Ezra founded his prohibition of intermarriage on the text of Deut 7:3-6 that "Marriage with the Canaanite peoples will lead to idolatry," and that Israel's holiness "is indeed contrasted in direct fashion to the practices of other nations." These are resolute statements about the danger of apostasy as 
polluting the seed or the blood does not reappear. At the account of Ezra's commands and the ensuing separation, Ezra and Nehemiah's objective, no occurrence of the term בדל "separate" is associated with the term זרע in their two books, but rather בדל appears in terms of a separation between two concrete elements, the body of Israelites and the other nations. For example, in Ezra 10:11 we read: "separate yourselves from the peoples around you, and from your foreign wives;" in Neh 10:29: "all הנבדל who separated themselves from the neighbouring peoples for the sake of the law of God;" and in Neh 13:3: "ויבדילו they separated from Israel all the mixed multitude." The term זרע, supposed to mean "seed," is mentioned in just one occurrence, in Neh 9:2: ויבדלו זרע ישראל "those of Israelite descent had separated themselves from all foreigners." Clearly, the phrase זרע ישראל at the separation refers to the accomplishment of the hoped-for result of their intervention in the parallel phrase והתערבו זירעי in Ezra 9:2, which must be interpreted as the children of Israel בני ישראי, who stood there and confessed their sins (Neh 9:2), ${ }^{61}$ like the many biblical phrases זרע ישראל with the identical meaning. ${ }^{62}$

We observe that at the successful conclusion of the crisis the author does not describe the Israelites' separation from נשים נכריות "the Gentile women," a phrase used in the books of Ezra and Nehemiah regarding the intermarriage issue, but their separation from "all foreigners." By separating from their Gentile women, the Israelites accomplished their segregation from the alien people, the primary divine command; thus, they could confess their sin of having transgressed it by intermarriage. And as here זרע ישראל relates to the "chilזי זרע Iren of Israel," the scriptural sobriquet for the Israelite people, the phrase הקדש, its counterpart, must be interpreted as "the holy people," an attribute

Ezra's motive for his decree, an assertion which in my opinion requires the interpretation of זרע הקדש as the holy people; Kugel, however, subsequently interprets it as "holy seed," whose mixing would consist of "a violation of cultic law," like "kilayim, namely 'sowing with mixed seed.' " There is no hint in Ezra of such allegation, and in my opinion his conjecture conflicts with his viewpoint about Ezra's motive, as cited above.

61 The LXx translates it thus: oi vioi I $\sigma p a \eta \lambda$ "the sons of Israel" versus viov $\alpha \lambda$ orpiou "the sons of the foreigners."

62 See for example 2 Kgs 17:20; Isa 45:25; Jer 31:35; Ps 22:24; and 1 Chr 16:13, which must be interpreted as בני ישראל "the children of Israel." Fensham, Ezra and Nehemiah, 125 translates the phrase זרע הקדש in Ezra 9:2 as "the holy people," relying, among other arguments, also on the phrase זרע ישראל in Neh 9:2. He further writes: "The term 'holy' shows that the term 'seed' has nothing to do with racial prejudice. It is the people whom God had elected as his people" (Exod 19:6). 
of the Israelites ${ }^{63}$ bestowed on them in Lev 20:26 on account of their concrete separation from other nations; there is no mention here of seed. ${ }^{64}$ Moreover, since the woman has no seed in the ancient Jewish view, there is no mixing of Israelite and foreign seed in a union between an Israelite man and a foreign woman. ${ }^{65}$ Although Abraham sired Isaac upon Sarah, an "Israelite" woman, and Ishmael upon an Egyptian woman, both are perceived by God as the exclusive

63 The phrase עם קדוש appears in Deut 7:6; 14:2 and 21. The term קדושים appears in Lev 11:44, 45; 19:2; 20:7 and 26; and Num 15:40.

64 Bob Becking, Ezra, Nehemiah, and the Construction of Early Jewish Identity (Tübingen: Mohr Siebeck, 2011) at $5^{2}$ writes that the concept of holy seed "is a combination of two traditional depictions of Israel: the idea of Israel as a 'holy nation' and its depiction as the 'seed of Abraham.' " At 53-4 he interprets Ezra's quotation of Deut 7:1-5 as relating to the aliens' uncleanness or pollution, having conducted abominations, founded on the term נדה in Ezra 9:11, as referring to "moral turpitude." As it seems to me, Becking does not articulate a clear and defined vision of Ezra's motive for his prohibition of intermarriage, citing apparent contradictory assumptions; at $55^{8-59}$ he states that the election of Israel created a biologically entity that may not be defiled by foreign elements, versus the assertions at 60 that intermarriage and that the foreign women "would almost certainly lead to syncretism and apostasy" and "formed a threat for the pure form of Yahwism." At 99, Becking quotes and translates Timo Veijola's assertion in Moses Erben: Studien zum Dekalog, zum Deuteronomismus und zum Schriftgelehrtum (Stuttgart: W. Kohlhammer, 2000) 230: "Both Ezra and Nehemiah—do not condemn the exogenous marriages on ethnic, racist or ritual grounds, but on a confessional basis," an assertion with which he seems to agree. Becking may perceive a double motivation: the issues of identity and of evil influence. In my opinion, the issue of identity and of drawing a borderline between Israel and "others" is also the consequence of the desire to preserve the purity of the particular Israelite culture, as opposed to Israelite biological purity. We observe that a number of scholars hesitate to take a defined position regarding the conflicting data between the general attitude of the entire text in Ezra and Nehemiah clearly pointing at their concern about the perseverance of the Jewish particular culture amidst the surrounding pagan world, and the motive of "holy seed," as they perceived it. The failure to grasp that the term זרע, like many other biblical terms has many meanings other than seed, is hard to comprehend.

65 The phrase אשה כי תזריע, ( Lev 12:2) which may allude to the idea that the woman contributes seed, does not conflict with this statement, reflecting assumptions in the biblical and later periods until the developments of physical principles in the 19th Century. In fact, the LXX translated it $\sigma \pi \varepsilon p \mu \alpha \tau i \sigma \theta \hat{\eta}$ "to beget," but in passive mode, namely begot by the man's seed. Both the KJV and the NIV likewise interpreted it in a passive mode; "if a woman have conceived seed," and "a woman who becomes pregnant." B. Nid. 31 refers it to the woman's discharge at intercourse, adding that if the woman discharges before the man, she bears a male; it explains the succeeding text of the verse "and gives birth to a son." Tirzah Z. Meacham in her dissertation Mishna Tractate Niddah with Introduction. A Critical Edition with Notes on Variants, Comments, Redaction and Chapters in Legal 
seed of Abraham, without any admixture of foreign seed (Gen 21:12-13). ${ }^{66}$ Along similar lines, I disagree with Schiffman's interpretation/translation of the term והתערבו in Ezra 9:2 as "diluting of their holy seed."67 Philologically the root of ערב in Hithpael means "mingled," as in Prov 14:10 and in Ps 106:35. The latter, stating that the adoption of foreign customs is the result of intermingling with them, is an exactly parallel issue to our verse Ezra 9:2.

Nehemiah offers us further evidence of the motivation to extend the restricted biblical prohibition on defined alien women to all foreign women. He justifies the intermarriage prohibition in Neh 13:25 by his observation that the sons of the foreign women did not know the Jewish language (13:24). The lack of knowledge of the Hebrew language is not a transgression of the law, which would justify the prohibition of intermarriage, and a fortiori the expulsion of the married women and their offspring; hence, we must attempt to understand the circumstances that induced him to perceive it as a serious menace to the survival of the Jewish people and their particular culture, and to act vigorously to prevent it.

It seems to me that Nehemiah drew the following conclusion from the foreign women's comportment: contrary to the hitherto common custom according to which Gentile women married to Israelites became Jewish, just as any woman became part of her husband's household and way of life, their sons' comportment demonstrated that they did not agree to follow that custom. ${ }^{68}$ Their refusal to learn and to speak the Hebrew language indicated their reluctance to adhere to the Jewish people and fulfill the Torah laws; ${ }^{69}$ the women and their offspring desired to remain involved with their foreign families, unlike those who separated from the unclean practices of the Gentiles (Ezra 6:21 and Neh 10:29 [28 in the $\mathrm{KJV}]$ ) and were recognized as part of the

History and Realia (presented at the Hebrew University, Jerusalem, 1989) writes extensively on this verse according to ancient and modern, physiological and linguistic aspects. Gen. R. 17:8 has a similar dictum: "Why does the man entrust [his] seed to the woman and the woman does not entrust seed to the man."

67 Schiffman, "At the Crossroads" $115^{-56}$ at 121.

68 Becking, Ezra, 103 asserts in this connection: "The inability to speak Judean most probably is remarked here as a sign of alienation from the Judean/Yehudite/Yahwistic identity as favoured by Nehemiah."

69 Joseph Blenkinsopp, Ezra/Nehemiah: A commentary (Philadelphia: Westminster Press, 1988) at 363 writes that "What was really at stake was not so much speaking a foreign language as the inability to speak Hebrew," that "language has always been an important ingredient of national identity," and "that Nehemiah's religious measures were part and parcel of a larger objective, namely, the survival of a 'people,' was easily neglected.” 
Jewish people. ${ }^{70}$ This fact constituted a great danger of assimilation of the Jewish minority (as it was at that time) by the surrounding idolatrous nations, ${ }^{71}$ and therefore Ezra and Nehemiah decided to apply the drastic measure of expulsion, although, according to the contemporary law, the children born from the seed of Jewish men were Jews, ${ }^{72}$ as I have demonstrated. ${ }^{73}$

\subsubsection{Interpreting Pollution and Cleansing}

Before proceeding with my arguments against Hayes' theory that the mixing of the Israelite seed with foreign seed was the basis of Ezra's blanket intermarriage prohibition, based on the phrase זרע הקדש, I shall briefly describe and also dispute Saul Olyan's similar theory, deduced from the same phrase, that the mixing of the blood types was its foundation. ${ }^{74}$ In contrast to Hayes, Olyan perceives a new, two-pronged conceptualization effected by Ezra and Nehemiah that induced them to extend the restricted biblical intermarriage prohibition to all aliens. The first is the "notion that all things alien are polluting," and the second "that intermarriage with aliens pollutes the bloodline." Olyan corroborates

70 Daniel Schwartz, "On two Aspects of a Priestly View of Descent at Qumran," in Archeology and History in the Dead Sea Scrolls (ed. Lawrence H. Schiffman, Sheffield: Jsot Press, 1990 157-179, at 165-6 claims that Ezra, a Zadokite priest, obviously rejected the possibility of conversion; marriage with foreign wives constituted pollution of the "holy seed." Consequently, he argues at 174 note 41 that "all who had separated themselves from the unclean practices of their Gentile neighbours (Ezra 6:21) were initially Israelites, and were now accepted, because they were of Israelite genealogical stock. I would argue that at Ezra's time conversion, as we know it today, was not yet established in Israel. Lawrence H. Schiffman, "At the Crossroads: Tannaitic Perspectives on the Jewish-Christian Schism," in Jewish and Christian Self-Definition, Vol. 2: Aspects of Judaism in the Greco-Roman Period (ed. E.P. Sanders et al.; Philadelphia: Fortress Press, 1981) 115-56, at 120 states that "there could not have been an institution for religious conversion at this time [of Ezra]."

71 Blenkinsopp, Ezra/Nehemiah, 361 comments on Nehemiah's record of the intermarriage crisis in Neh 13:23-31 under the subheading "Nehemiah's Anti-Assimilationist Policy." This indicates Blenkinsopp's opinion on what constituted the core of the extension of the intermarriage prohibition.

72 Schiffman, "Tannaitic Perspectives," at 121 asserts that "Neh 13:23 once again emphasizes that these children were regarded as not Jewish." I dispute his assertion that has no basis in Scripture; on the contrary, as I demonstrated on pp. 304-305 they were ethnically Jews. Moreover, Nehemiah's accusation that they do not speak Hebrew, would be senseless if they were not Jewish.

73 See a more extended discussion of this particular issue in Heger, "Patrilineal or Matrilineal" at $239-242$.

74 Saul M. Olyan, Rites and Rank: Hierarchy in Biblical Representations of Cult (Princeton, NJ: Princeton University Press, 200o) 82-84. 
ויטהרו :-13:4 and they purified the rooms [in the Temple]." Olyan interprets the term טהר הere as a ritual purification, necessary because Tobiah the Ammonite, an alien, had been there; thus, it is demonstrated that aliens pollute.

The Hebrew terms טמא חהר חלל טהר and, like have a wide range of meanings ${ }^{75}$ the term טהר is used, for example, to mean cleansing from sins in Lev 16:30, clear as the sky in Exod 24:10, pure gold in Exod 30:35, healed from leprosy in 2 Kgs 5:12, pure eyes not to look on evil in Hab 1:13 and finally clean from/clear out in $2 \mathrm{Chr}$ 34:3, which I believe is the most appropriate match for the correct interpretation of Nehemiah's assertion; it relates to a comparable issue of cleaning out iniquitous artifacts, and both texts are from the Second Temple period, in which we encounter many novel terms and meanings. We read there: "he began to purge לטהר Judah and Jerusalem of high places, Ashera poles, carved idols and cast images." The passage does not say that Josiah cleansed Judah and Jerusalem, but rather that he disposed of or cleaned out the idolatrous artifacts from Jerusalem, and in Neh 13:4-9 we find the same meaning: he cleaned out from the rooms all of Tobiah's belongings.

The phrase וטהרתים מכל נכר "I cleaned them [the priests] from all foreigners," similarly cannot be interpreted as ritual cleaning, and must instead be interpreted as cleaning/removing all that is foreign, as in the cleaning of or removing from the rooms in Neh 13:9. Olyan, however, perceives it as further evidence for the theory that aliens represent a pollution. Moreover, the ritual pollution of a person or a substance has no affinity with an abstract defilement of blood. Scripture uses different terminologies for the status of the offspring of forbidden marriages than for ritual pollution. The first is denoted by חלל, טמא טמא טמא In his description of the foreigners, Ezra uses the term in Ezra 6:21, in the sense of their wickedness and as the motive for his provision to separate from them לדרש לה' אלהי ישראל in order to worship the Lord, in

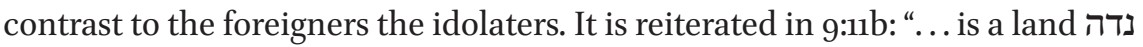
impure with the בנדת impurity of the peoples of the lands, with their abominations that have filled it from end to end with their בטמאתם uncleanness."

Thus, the evil deeds of the people who made the land impure formed the motive for the separation of this group, as we see in Ezra 6:21, and for Ezra's decree of separation from them, as is evident from their portrayal in Ezra 9:11 in his justification for the decree. Finally, as it seems to me, Olyan's claim is

75 Mila Ginsburskaya, "Leviticus in the Light of the Dead Sea Scrolls: Atonement and Purification from Sin," in The Dead Sea in Context; Integrating the Dead Sea Scrolls in the Study of Ancient Texts, Languages, and Cultures (eds. Armin Lange et al.; Leiden: Brill, 2011) 263-277, at 272 ff. analyses the copulas טהר + כפר, טהר + סלח ,סלח + כפר. 
untenable because of a key flaw in his argument, namely that a building of stones or wood, as the rooms in the Temple were, does not become ritually polluted, and hence does not need ritual cleansing. The phrase ויטהרו "they purified/cleaned (the people and) the gates and the wall" (Neh 12:30) must also be perceived merely as cleansing of abominable things, since nowhere in Pentateuchal law do we encounter a ritual cleansing of gates and walls. ${ }^{76}$ The only structure to require ritual cleansing is the house cleansed of mildew (Lev 14:49-53), which is to be explicitly declared unclean and closed before the contaminated stones are taken out.

While he confirms that in earlier texts, namely before Ezra, "an alien mother did not affect a child's Israelite ancestry as long as the child's father was an Israelite," alluding that it was no longer applied in Ezra's period, ${ }^{77}$ Olyan appears to have overlooked the significance of Ezra 2:59 and Neh 7:61, cited above, which clearly confirm that Ezra and Nehemiah continued practising according to the ancient law that the father, not the mother, establishes the offspring's ethnicity. Because of this presumed oversight, he searches for a motive for what he takes to be a "major innovation" on the part of Ezra and Nehemiah that "the native category belongs only to those whose parents are both classed as Israelites,"78 a statement which I feel does not concord with reality. To rationalize this innovation, Olyan claims that Ezra alluded in his citing of abominations in Ezra 9:2 to Lev 18:26-30, verses that relate to defiling sexual abominations, thus justifying the absolute exclusion of all defiling aliens from cult and community. My understanding of Ezra's text avoids such tortuous cogitation.

\subsection{Disputing Hayes' Theory}

\subsubsection{The Core of the Theory}

Hayes' core assertion is that the underlying rationale for the ban on interethnic sexual unions that she observes in Jubilees and in 4QMMT is not the fear of

76 Num 19:14-15 specifies that anyone who enters the tent and what is inside it, rather than the tent, becomes polluted. However, since v. 18 may be perceived as suggesting that the tent becomes polluted as well, and must be cleansed by sprinkling, the rabbis decided that only a tent made from linen cloth is affected, such as the cover of the Tent of Meeting (m. Shabb. 2:3 and b. Shabb. 28a); dwelling structures of other materials such as wood or stone, do not become polluted, and do not require cleansing.

77 Olyan, Rites and Rank, 89 .

78 Ibid., 89 . 
contracting ritual impurity from a Gentile, a view I fully endorse, but rather the fear of profaning the holy seed of Israel—an entirely new and distinct concern, which she suggests was Ezra's innovation. At the outset of her thesis, Hayes acknowledges that the biblical rationale against intermarriage with the Canaanites because of turning the Israelite partner to idolatry can be logically extended to intermarriage with any Gentile, the argument I postulate as the rationale of Ezra's decision, but since such an argument would undermine her theory of seed purity - the only determining motive she chose among many possibilities ${ }^{79}$ — she argues that "only those exogamous unions that result in the moral or religious alienation of the Israelite partner are prohibited," but "at the same time it does not render the law of universal application," ${ }^{\prime 80}$ in contrast to Ezra's decree, which in her opinion does not discern between exogamous unions in this way.

This line of argument seems to me lacking in coherence. Although Deut 7:4 uses the term כי יסיר "for he will [turn your son away]," rather than the term פן "eventually/he may," as in Gen 3:3, in neither case does the meaning convey that it will surely happen; the term in Deuteronomy is in the progressive future mode, which indicates its possibility, but not its absolute necessity. There was as yet no conversion in Israel at that period, and therefore there was no official method to ascertain prior to marriage whether a woman would want to join the Jewish people with its faith and culture; hence a universal prohibition of intermarriage was the only sure method of avoiding the evil influence of idolatrous women. Moreover, as I understand Nehemiah's concern (see pp. $325 \mathrm{ff}$ ), the Gentile women and their offspring did not a priori want to join the Jewish people or its culture.

Hayes builds her theory on the assumption that since "Deut 21:10-14 permits marriage to a beautiful captive woman ... the women of foreign nations are considered to be ultimately assimilable, while those of the seven Canaanite nations are not." Hence Ezra's universal prohibition of intermarriage must have another motive, and that, argues Hayes, is to avoid the admixture of the holy seed ${ }^{81}$ By this device, however, she cuts off the branch she is sitting on. The

79 Johnson, The Holy Seed, 15 writes: "For contemporary interpreters, Ezra-Nehemiah makes possible the exploration of several germane matters because the intermarriage dilemma is a multidimensional phenomenon which poses questions related to gender, sexual, economic, and religious issues."

$80 \quad$ Hayes, "Intermarriage and Impurity," 7.

81 Ibid., 8 states indeed in note 15 that Louis Epstein, Marriage Laws in the Bible and Talmud (Cambridge, MA: Harvard University Press, 1942), 158-59 "that war captive wives and foreign slave wives are permitted because the Gentile partner is clearly in an inferior 
concept of assimilability or otherwise is clearly a cultural affair, entirely distinct from the issue of race or seed; hence, it would follow from Hayes' assumption that the motivation of the intermarriage prohibition is the danger of acculturation rather than of seed intermixing. Moreover, it would seem that based on this assumption, there is no mixing of holy and unholy seed at the marriage with Gentile women, except with Canaanites, and hence intermarriage with non-Canaanite foreign women should be permitted. Ezra, however, prohibited intermarriage with all foreign women, including those previously considered assimilable.

I would argue in any case that Hayes' reading is anachronistic. Admixture of seed or race was not in the mind of Ezra or of the general society at that time; Scripture records intermarriages of Israel's most revered personages, and the fact that intermarriage was practised by the entire Israelite aristocracy of the highest rank, of both political and religious circles, including the genealogically cognizant priests, demonstrates that in marriages the superiority of seed or race - the difference is semantic - was an unheard-of concept. Intermarriage was not seen as taboo even at the later time of the Hellenistic era: Alexander the Great married Roxane, a Persian (Bakhtian) princess, and commanded his officers to do likewise to foster the spread of Hellenistic culture in the East or throughout the oikumene. Alexander's goal, and intermarriage as the most efficient method to attain it, were precisely what Ezra attempted to avert by his prohibition. The mixing of races or seed in the modern sense was of no concern to Alexander or to the Greek people, although the question whether the Greeks perceived themselves as superior to other nations is a debated topic. ${ }^{82}$

The Maccabean revolt of $167 \mathrm{BCE}$ was a response to the cultural Hellenization process; intermarriage, as it seems, was of no concern and is not mentioned

position and thus not able to impose her idolatrous practices upon her captor or master, but must accept Israelite religion," a logical opinion that fully supports my thesis, but since it refutes her theory, she ignores it and clings to her idea of discerning between some "seeds/races," who are "assimilable" according to their particular character, and others who are not, instead of considering the political circumstances explicitly portrayed in Deuteronomy 7:1: when you enter the Canaanites' land, who will not be driven out immediately (Exod 23:29-30) as was the situation facing Ezra and the returnees-as opposed to a single captive woman after victory in war.

82 The requirement of being the offspring of both Athenian father and mother to be eligible as an Athenian citizen has no association with race. In fact, at the "end of the fifth century, the number of the citizens was then reduced on the basis of a wealth quota." See Ida Fröhlich, "Mamzer in Qumran texts— the problem of mixed marriages from Ezra's time. Law, literature and practice," Transeuphratène (2005) 103-115, at 107-108, with indications of her original sources. 
anywhere in accounts of the revolt. Acculturation, not racial or seed seclusion, was the name of the game at that period. Ezra's logical basis for his decree, as presented by Hayes, has an intrinsic flaw: if Ezra had taken the liberty of promulgating a rule to prohibit the mixture of Israelite seed with that of other nations, explicitly extraneous of Scripture as Hayes claims, he could instead have extended the existing biblical prohibition of the Canaanites, as he indeed did, without devising a new concept that was unfamiliar in past Jewish society and would be rejected in the future. Ezra's decree, driven by the danger of potential apostasy, pertinently and clearly justified in the Ezra text, as I postulate, is not an extra-biblical rule; it is no different from the logical extension of the biblical law of Exod 21:33-34 that a man who uncovers a pit must pay for the loss of a sheep that has fallen in, although Scripture mentions only an ox or a donkey. ${ }^{83}$ Similarly, he would be liable if he created another impediment in the public domain and caused a loss to someone's livestock, although Scripture mentions only a pit. This is exactly analogous to what Ezra has done in his logical and legitimate extension of the boundary of the biblical law of Deut 7. According to Hayes, however, Ezra devised a new law, extraneous to Scripture, and transgressed the biblical prohibition to add to or revoke one of the given precepts (Deut 13:1, 12:32 in KJV). ${ }^{84}$ While she writes that Ezra added an entirely "new rationale" to the older "Torah rationale," in fact, as she argues it, he added a new law, a prohibition against the mixing of races, on the basis of this rationale.

Hayes claims that Ezra compared the holy Israelites to the priests: both were separated from a large group, and "as the priest's holy seed is preserved by means of certain marriage restrictions, so also are marriage restrictions needed to preserve the holy seed of the ordinary Israelite." ${ }^{85}$ This conjecture is logically flawed, since she draws a conclusion founded on the unproven concept of holy seed, and constructs upon it a further assumption of her own. Furthermore, as I have demonstrated (pp. 303-304), the biblical restrictions imposed on priestly marriage are not associated with the preservation of their holy seed; all Israelites are holy, but the marriage restrictions for the High priest, the ordinary priests and the Israelites are each different (as are other rules and restrictions). The issue of the preservation of holy seed is not mentioned, nor hinted at in Lev 21, the source of the priestly marriage restrictions.

Hayes' assertion that in the Restoration period a universal ban on intermarriages was instituted "for the novel reason that marital union with a

\footnotetext{
83 See m. B. Qam. 5:7: "Scripture uttered what is common."

84 In b. Shabb. 104a, the rabbis deduce from this verse that even a prophet may not add any precept to those of the Torah.

85 Hayes, "Intermarriage and Impurity," 9.
} 
Gentile profanes (that is, renders non-holy) the holy seed" has no textual foundation. ${ }^{86}$ The text of Ezra 9:1-2 she quotes does not say this; at this stage in her argument she is still in the process of attempting to prove it. Mal 2:11-12 cannot serve as evidence, as she suggests, since the issue of holy seed does not appear in these verses. Further, the phrase בת אל נכר in Malachi, criticizing the marriage of women who worship a foreign god, indicates the focus of the evil deed: namely, the danger of idolatrous influence seems to support the identical motive for Ezra's decree. Moreover, the name and date of the author of Malachi is unknown and a matter of some speculation. B. Meg. 15a hypothesizes that Ezra is its author, while scholarly conjectures perceive an association of many circumstances in Malachi with those recorded in the books of Ezra and Nehemiah. Hence, it should not be surprising that the prophet refers to Ezra's prohibition against intermarriage. Finally, some scholars hypothesize that some later additions were made to the original texts, and our v. 11, part b to be precise, is perceived to be one of them. Drawing halakhic or doctrinal conclusions from poetic prophetical texts is akin to walking through a minefield, particularly regarding verses such as ours, with a doubtful history.

\subsection{2 מעל:Desecration or Transgression?}

Hayes is aware that "Ezra does not use the term nלל profane to describe [the consequences of] intermarriage," 87 used in Scripture at the portrayal of the offspring of a prohibited priestly marriage, the core of her thesis that intermarriage of an Israelite with a Gentile profanes the holy seed, since Ezra compared the holy Israelites to the priests, as cited above; she attempts, therefore, to prove her case on the basis of the term מעל used by Ezra: "And במעל הזה in this faithlessness the hand of the officials and chief men has been foremost" (Ezra 9:2), and in consequence, as recorded in Ezra 10:19, they brought a ram as a guilt offering after pledging to put away their wives. Hayes interprets the term מעל referring to intermarriage with foreign women as "a technical term

86 Ibid., 10. Fröhlich, "Mamzer in Qumran," at 106-107 interprets Ezra 9:1 "The holy race has become mixed with the alien population," a concept that is undefined and could mean the holy people, such as a nation, or signify the modern sense of race. On the other hand she writes: "Ezra's measure seems to sharpen the division between Jews and their neighbours," a statement that seems to emphasize the division between the peoples, rather than the mixture of races, as Ezra's motive for promulgating the prohibition of intermarriage with all alien nations. Fröhlich does not, however, attach much significance to the issue of what the phrase זרע קודש means, since the core of her interest is another topic, the comparison with the Athenian rule of citizenship.

87 Ibid., 10. 
connoting desecration or profanation of a sanctum," 88 like the guilt associated with involuntary use of holy things (Lev 5:15-16), for which a ram must likewise be brought as a guilt offering. As evidence for support of her thesis, I perceive this argument as "a splintered reed of a staff" (2 Kgs 18:21 and Isa 36:6).

The term מעל in our verse is translated as "trespass" in the KJv, "unfaithfulness" in the NIV, "faithlessness" in the RSV, $\alpha \sigma \nu \nu \theta \varepsilon s i \alpha$ "contrary to the covenant/ agreement" in the LXX and transgressione "transgression" in the Vulgate. But none of these translations/interpretations fit Hayes' theory of profanation of a sanctum, and therefore she chooses the one scriptural occurrence of the term that relates to sacrilege, an instance that has no logical association with intermarriage and no corresponding legal consequence (how would the sinner add a fifth of the value, decreed in Lev 5:15, quoted by Hayes as evidence?), ignoring the many other occurrences of the term that are more appropriate to understanding Ezra, as I shall now demonstrate. The term מעל טמל, like similar terms such as טהר and has a broad range of meanings or rather applications according to the context, but its generic meaning connotes something done that is wrong, and it is used in Scripture mainly to indicate a breach of trust amongst people or between people and God. In Jewish creed, from its inception and in contrast to the pagan religions, doing evil to a person is a sin against God and a breach of His trust, as we read in Lev 5:21: "If anyone sins ומעלה מעל and commits a breach of faith against the LORD by deceiving his neighbour in a matter of deposit or security, or through robbery, or if he has oppressed his neighbour." ${ }^{89}$ Notice that in this case, the sinner did not desecrate or profane a sanctum, but cheated his neighbour, and he must therefore bring an asham "guilt" offering as indicated in Lev 5:25. ${ }^{90}$

We encounter a similar eventuality and the use of identical terms in Num 5:6-7, in which a breach of trust against another person is called מעל and requires an asham offering. The term מעל is used at the misbehaviour of the suspected Unfaithful Wife (Num 5), and at various misconducts in Lev 26, Deut 32:51, Ezek 39:23, and in other occurrences, all unconnected with sacrilege.

\footnotetext{
88 Ibid.

89 Rothenbusch, "The Question of Mixed Marriages," at 67 writes: "Both terms [מעל and [שע express 'infidelity,' targeted mostly against YHWH, but they can also refer to infidelity against people."

9o See also K. Southwood, Ethnicity, 89-9o for arguments against Hayes' assumptions deduced from the use of the terms מעל משם by Ezra.
} 
Moreover, the term מעל is used in 2 Chr 36:14, an almost verbatim parallel condemnation of abominable practices to our verses in Ezra 9:1-2. ${ }^{91}$ The condemnation, and the term מעל, do not relate to intermarriage or to any transgression associated with sacred things, but to wicked deeds, like the abominations of the nations that defiled and desecrated the divine Temple, causing its destruction and the exile (Lev 18:28; 20:3; 22; Num 35:34). Ezra warns the people to avoid such behaviour, engendered by intermarrying with these nations, as might precipitate the same repercussions; on the other hand, he promises them that through obedience to the divine rules they shall be strong, eating the good things of the land and leaving it as an inheritance for their children..$^{92}$

\subsubsection{The Significance of the asham (Guilt) Offering}

Hayes' argument addresses Ezra's decree that those who married foreign women must bring an asham (guilt) offering (Ezra 10:19). She argues, erroneously in view of my findings, that this transgression was perceived as a sacrilegious mixing of the holy seeds, thus requiring the guilt offering for its expiation, like the same offering to be brought for enjoying sacral food in Lev $5: 15^{-16.93}$ While it is true that the latter verse refers to sacrilege, she ignores the fact that Lev 5 enumerates a great number of sacrilegious transgressions which do not require a ram guilt offering, and non-sacrilegious transgressions that do

91 The NIV and the KJV do not translate the term מעל מעל מעל, and interpret its double mention as "transgressed very much," associating it with all the abominations of the heathen. The LXX doubles the term $\alpha \theta \varepsilon \tau \omega \varsigma$ "lawlessly, despotically" (Liddell and Scott). Albert Pietersma and Benjamin Wright, in A New English Translation of the Septuagint (Oxford/New York: Oxford University Press, 2007), interpret it: "multiplied violating with violations of abominations." There is no hint of sacrilege or impurity in all these translations and interpretations. The Greek translation of 1 Esdras 8:66, the parallel of Ezra 9:1, which mentions the term $\alpha x \alpha \theta \alpha \rho s i \alpha$ "impurity," quoted by Hayes as support for her thesis, cannot contradict the original Hebrew text and the great variety of translations cited above. It is plausible that the author of 1 Esdras used in his Hebrew original writing Ezra's terms, and we cannot speculate why its Greek translator deviated from the plain sense of the original text.

92 Jan Clauss, "Understanding the Mixed Marriages of Ezra-Nehemiah in the Light of Temple Building and the Book's Concept of Jerusalem," in Mixed Marriages, 109-131, at 130-131 states: "The obligation to endogamy is an ethical requirement due to Israel's essential trait- the exclusively close relation to YHWH." I fully agree with this statement, and also with Clauss' assertion that "the mixed marriages [should be understood] as a sacrilege committed against the sanctuary," because the idolatrous worship resulting from these marriages leads to the defilement of the Temple, as indicated in Lev 20:3. 
require just such an offering. In the first group, not requiring an asham, vv. 2 and 3 relate to sacrilegious transgressions, while vv. 1 and 4 do not. ${ }^{94}$ In the second group, which do require a ram as a guilt offering, only one, in vv. $15^{-16}$, refers to a sacrilegious transgression, whereas all the others (vv. 17, 21, 22 and 24) refer to non-sacrilegious transgressions. Hayes, however, chose from this great array of cases the only one that matched her argument.

Hence only the specific transgression of involuntary use of holy things as recorded in Lev 5:15-16 requires a guilt offering. Therefore Ezra's command to bring a guilt offering for the transgression of intermarriage could not have been derived from this biblical rule, completely different in its type of transgression and legal consequence: it did not require to pay the fine of a fifth, as Leviticus decrees. Hence, it cannot serve as support for Hayes' theory.

Moreover, the fact that Ezra's decree demands an asham sacrifice of those who have intermarried does not serve as evidence that it should be equated with or considered comparable to the biblical asham offering for inadvertently using sacred property, since Ezra also instituted other offerings that have no scriptural basis, such as, for example, the novel concept that community offerings must be twelve in number, corresponding to the twelve tribes of Israel, 95 as explicitly stated in Ezra 6:17.96 In Ezra 8:35 we encounter bizarre types and numbers of offerings: "twelve bulls for all Israel, ninety-six rams, seventy-seven male lambs, and as a sin offering twelve male goats, all a burnt offering to the

94 Although Scripture does not elucidate the nature of the sins in vv. 2 and 3, it is clear that he entered a holy place or touched holy things in his polluted state, forgetting his uncleanness. (M. Sheb. 2:5), since becoming polluted by touching a carcass is not a sin in itself. The offering for the transgressions in vv. 1-4 is a חטאת "sin offering," not an asham. The numerous mentions of the term חטא in various grammatical forms, and the offering of a sheep or a goat as for a sin offering, not of a ram for an asham, serve as evidence for the type of the offering (b. Kerit. 27b).

95 S. Talmon, The World of Qumran from Within (Leiden: Brill, 1989), $41 \mathrm{ff}$. speculates that the twelve offerings were to demonstrate that only the returnees were the genuine Jewish people. On the identity of צרי יהודה ובנימן "enemies of Judah and Benjamin" in Ezra 4:1 and "the peoples around them" in v. 4, possibly linked to this topic, see also Lester L. Grabbe, Ezra-Nehemiah (London-New York: Routledge, 1998), 137, and P.R. Davies, "The birthplace of the Essenes: where is “Damascus?" RevQ 14, 4 (1990) 503-519, at 514.

96 The twelve male goats offered by the twelve tribal leaders at the Tabernacle's consecration (Num 7:2-8) are of an entirely different character than the concept of twelve offerings instituted by Ezra. The latter were clearly offered by the people as a sin offering "for all of Israel," whereas in Numbers these offerings—among many others—were given by the leaders on their own behalf. 
LORD." ${ }^{97}$ However, no pentateuchal requirement for the number of twelve sacrifices, nor its multiples, nor the strange number of seventy-seven lambs for sin offerings, is recorded for any of the sacrifices, whether obligatory public offerings, the daily offering, ${ }^{98}$ or the communal sin offerings. ${ }^{99}$ Moreover, the biblical asham offering is brought only for involuntary sins, yet intermarriage in Judah does not seem to have been involuntary. We observe the opposition Ezra and Nehemiah encountered in their efforts to enforce the intermarriage prohibition. ${ }^{100}$ Their dramaturgic spectacles (Ezra 9:3, 4; 10:1; Neh 13:25), and as the last resort threatening the confiscation of property from those who would disobey (Ezra 10:8), confirms the assumption that the intermarriage of the people did not have the character of an involuntary offence that one attempts to redress after becoming conscious of its sinful aspect. Last not least, as it seems from the text of Ezra 10:19, the asham was offered only by the priests, whereas the laics, the majority, did not bring it. ${ }^{101}$

In view of all these facts, the asham/guilt offering instituted by Ezra cannot serve as evidence that intermarriage constitutes a sacrilegious sin or that he perceived it as such, and therefore decreed it.

\subsubsection{Intermarriage: Cultural Dilution, Not Profanation}

Hayes cites as further support for her thesis the fact that "the prohibition on intermarriage with Canaanites in Deut 7:2b-5, upon which Ezra clearly relies, is followed immediately in v. 6 by the statement 'For (כי) you are a people consecrated קדוש [holy] to the LoRD your God."'102 She perceives this verse as the justification for the prohibition of the preceding v. 3, writing: "do not

97 The numbers of the offered animals are multiples of twelve, except for those of the lambs, which are multiples of seven and eleven. B. Tem. $15 \mathrm{~b}$ correctly presumes that the multiple of twelve corresponds to the twelve tribes, but declares that the offering of the peculiar number of lambs was an extraordinary, ad hoc command.

98 See Exod 29:38-42, as well as vv. 43-45 which relate the sacrifices to God's presence and His dwelling among the people of Israel.

99 Only one ox is required as a sin offering for a transgression by the Israelite community (Lev 4:14); on the Day of Atonement, two goats are required, one as a regular sin offering and one as a scapegoat (Lev 16:15-20).

100 Joseph Blenkinsopp, Ezra-Nehemiah, 177 writes that the "measures taken by Ezra against intermarriage were not successful."

101 Maccoby, "Holiness and Purity," 166-68 claims that the Jewish women who remained in the land, but married priests from the returnees committed a sacrilege by eating the holy food permitted only to priests and their household, because they were not recognized as Jewish by Ezra. Therefore, Ezra decreed that the priests must bring a guilt offering.

102 Hayes, "Intermarriage and Impurity," 11. 
intermarry with Gentiles, for you are holy (my italics), adding the text from v. 6 to that of v. 3, and a devised explanation: while they are not. Just as a priest's marriage to one who is unfit profanes his holy status, so Israel will be profaned by marriage with those who are not holy." ${ }^{103}$ I thoroughly dispute her imagined and contradictory additions to the text. Deut 7:6 is not the justification/ explanation for the intermarriage prohibition in v. 3, which is justified by the succeeding v. 4 "for they will turn your children," but rather mainly for the decree in its preceding v. 5 to destroy their altars. The decrees of vv. $3^{-4}$ are distinct in their subject and character from those of vv. 5-6 or up to v. 11 . The first are in negative mood, referring to intermarriage, whereas the latter are in positive mood, referring to the destruction of their altars. It seems that Hayes has skipped over the content of v. 4, the obstacle to her theory, connecting v. 3 instead to v. 6 .

I similarly dispute the second part of Hayes' comparison- - Just as a priest's marriage to one who is unfit profanes his holy status, so Israel will be profaned by marriage with those who are not holy"104_on the grounds that the priest does not profane his own holy status by marrying an unfit woman, as Hayes claims, but profanes only his offspring (Lev 21:15). ${ }^{105}$ Hence, Hayes' comparison is flawed, since the priest himself is not profaned, and neither, we may conclude, is an Israelite who marries a woman prohibited to him. ${ }^{106}$

\subsubsection{Disputing Hayes' Support from Tobit}

Hayes' claim of support from Tobit, arguing that "Preserving seed is the concern of the book of Tobit," seems to me to be wishful thinking rather than a substantiation of her thesis. Tobi, Tobit's father, does not refer to marriage with a foreign woman in his advice to his son. Such marriage was prohibited by Ezra, and there is no need for Tobi to remind Tobit of the prohibition. And indeed, as is evident from the text of Tobit 4:12, he does not tell him that it was forbidden, as Hayes argues. He merely advises his son to marry a woman from his family, not from another Israelite tribe $(\varphi \nu \lambda \hat{\varepsilon})$, promising him an auspicious future if he does so, as happened with our ancestors the Patriarchs, who married from their own clan (Tobit 4:12b). The Book of Tobit was probably written originally in Hebrew, and the author may have used the term זרע, but as argued this term

\footnotetext{
103 Ibid.

104 Ibid.

105 This is the simple meaning of the biblical text, and is acknowledged as such in b. Qidd. $77 \mathrm{a}$.

106 In severe cases, such as marrying a mamzer, any offspring are defiled, but he himself is not.
} 
has many meanings, and as I will further corroborate, it must be understood here as descendants, rather than in terms of a racial concept of seed. The entire text relating to Tobit's marriage corroborates our thesis that Tobi referred in his advice exclusively to Sara, the daughter of his cousin Raguel, according to the author's careful plotting of the narrative.

Immediately after the portrayal of Tobit's lamentation because of his distressing conditions and the false reproaches he has heard, and his praying to God to relieve him from his affliction by taking his life (Tobit 3:6), the author inserts (vv. 7-15) the parallel misfortunes of Sara praying to God to take her life or to provide some pity for her not to hear further reproaches accusing her for the death of her seven husbands. The author starts the intercalation of the Sara narrative into the life of Tobit's family with the opening sentence at 3:7: "It came to pass in the same day" that both sad events occur, and makes it clear that divine help already reaches the united couple Tobit and Sara. We read in the concluding vv. 3:16-17a of this passage: "So the prayers of them both were heard before the majesty of the great God. And Raphael was sent to heal them both, that is, to scale away the whiteness of Tobit's eyes, and to give Sara the daughter of Raguel for a wife to Tobit the son of Tobi." The scheme of the narrative is now unveiled, and then follows its actualization, which adds further credible evidence that Tobi's initial counsel to Tobit related to his marriage with Sara. The same applies to Sara's burying seven husbands, because her destiny was to marry Tobit, and divine providence sent the angel Raphael to bring this to its fulfillment.

We read in Tobit 6:12-13 the angels' speech to Tobit: "and when we return from Rages we will celebrate the marriage: for I know that Raguel cannot marry her to another according to the law of Moses, but he shall be guilty of death, because the right of inheritance doth rather appertain to thee than to any other." In v. 16 the angel reminds Tobit of his father's mandate to him before his departure that he should marry a wife of "thine own kindred" (family). ${ }^{107}$ Now it is entirely evident that Tobi's mandate to his son in 4:12 has no suggestion at all of warning him not to marry a foreign woman, but rather of counseling him to marry Sara, dedicated to him by the law of Moses as we saw in 6:13, and further acknowledged in Raguel's speech to Tobit in 7:13. Nevertheless Hayes does not discuss these textual clues, claiming instead that Tobi warned his son not to marry a foreign woman, relying on her narrow interpretation of the term "seed."

107 For example, the translated phrase "thine own kindred," in 6:15, appears in the Lxx as

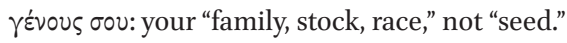




\subsubsection{Disputing Hayes' Support from Jubilees}

Hayes next attempts to adduce further support for her theory, claiming that Jubilees relied for its rules about intermarriage and its interpretation of Gen 34 on Ezra's decree. She starts by criticizing Cana Werman's theory about the intermarriage ban in Jubilees, ${ }^{108}$ because Werman "does not take into account the notion of holy seed and its ideological freight."109 I do not agree with all of Werman's theories and assumptions, but I dispute Hayes' reproach, because there is nowhere in Jub. 30 a mention of holy seed or of a prohibition to mix it with impure/profaned/defiled seed, the basis of Hayes' theory. Since she considers her theory as a given, however, she therefore criticizes Werman for not acknowledging it.

The term "seed" appears four times in Jub. 30; however, these instances cannot be interpreted as denoting the abstract seed, according to Hayes' assertion, but rather as a generic sobriquet for descendants, children or people. I have already demonstrated the many meanings of this term in Scripture and will now do the same regarding its use in Jub. 30. In v. 7, "any man who is of the seed of the Gentiles" must be interpreted according to the context, as denoting from the peoples/nations. An "abstract" interpretation of "seed" in the sense of Hayes' theory is inappropriate here. In fact, the author writes explicitly in Jub. 30:13: "those that take the daughters of the Gentiles" are denounced: "for this is unclean and abominable to Israel." This statement relies on Jacob's sons' assertion: "We will not give our daughter to a man who is uncircumcised." In v. 9: "written in the heavenly tablets regarding all the seed of Israel," the antithetical phrase to the seed of Gentiles in v. 7 must be interpreted likewise as the people of Israel or better as the common sobriquet בני ישראל "Israelites," as habitually translated. The qualifying adjective "all" (v. 9) excludes the possibility of relating it to "seed" in the sense of Hayes' theory. ${ }^{110}$ Verse 10, "he has given of his seed to Moloch," founded on Lev 20, which refers to actual children, along with its further comparison to the concrete affair of Dinah, excludes any possibility of relating the term to the abstract "seed." Verse 18, "And the seed of Levi was chosen for the priesthood," could be interpreted in either way, and therefore cannot serve as conclusive evidence for Hayes' theory. The term "holy"

108 Cana Werman, "Jubilees 30: Building a Paradigm for the Ban on Intermarriage," HTR 90:1 (1997) $1-22$.

109 Hayes, "Intermarriage and Impurity," 15.

110 Ibid.: "one need only point out that terms of defilement/impurity in Jubilees 30 always refer to (the seed of) Israel (vv. 8-10) (to which I referred in the text) or to the act of sexual union itself (vv. 8, 13-15), and never to the individual Israelite partner." In Jub. 30:13-15, however, there is no mention of seed. 
appears twice in $J u b$. 30, but never in association with seed. In v. 8 we read: "for Israel is holy unto the LORD," as we encounter in Scripture in association with obeying and fulfilling the divine precepts; ${ }^{111}$ sexual misbehaviour is only barely mentioned among other precepts, indicating its relative insignificance in determining the holiness of Israel. Such behaviour is, however, significant in association with polluting the land in Lev 18, and I shall revert to it in examining the array of meanings of the term טמא in Scripture in an appendix to this chapter. In conclusion, I believe that Werman was correct in not apprehending in Jub. 30 the notion of the mixing of the holy seed as the main motive of its narrative and halakhic decision, or in Hayes' characterization "its ideological freight."

Hayes also states that "Jub. 16:17-18 relies on Exod 19:6 to establish that Israelites and Gentiles are two distinct 'seeds' — one holy and one profane."112 Aside from the issue whether the translated term "seeds" is to be understood as "seed" in Hayes' sense, or as "children/descendants" — the meaning of the term זרע, the presumed original source of the translated "seeds," as I have arguedher claim has no textual support, since Exod 19:6 does not employ the term "seed,"113 and consequently cannot offer any suggestion of mixing holy and unholy seed in any case. Hayes does not quote Lev 20:26 (see p. 23), which explicitly indicates the holiness of Israel versus the other nations, in support of her thesis, because it would also clearly demonstrate that Israel's holiness is the consequence of physical separation from the other peoples, not the

111 The phrase גוי קדוש in Exod 19:6 is the consequence of obeying the unspecified divine commands mentioned in the preceding verse. The phrase אנשי קדש in Exod 22:30 is associated with fulfilling the rules of avoiding the consumption of carcasses and torn animals, וה in Deut 23:15 with proper sanitation, and עם קדוש in Deut 26:19 with accomplishing all precepts. The habitual term קדשים in Lev 11:44 is again associated with avoiding the consumption of forbidden animals, in Lev 19:2 with ethical behaviour; in Lev 20:7-8 it is used either with reference to obeying all precepts, including sexual misbehaviour of all kinds, if perceived as referring to the succeeding verses, or as an exhortation against idolatry, magic and sorcery if it refers to the preceding verses. In Lev 20:26, the term appears after ethical rules, a list of sexual misconduct, and forbidden consumption of unclean animals - the transgression which concludes the list, and which seems to be the critical motive for the separation of holy Israel from the other peoples, rather than sexual misdoings; in Lev 22:32, the term relates to the appropriate manner of offering sacrifice, while in Deut 14:2 it is associated with the prohibition of extreme signs of mourning, and in v. 21 with forbidden food and animals. The concept of holiness is intrinsically associated with real deeds, not with the abstract topic of mixing seeds.

112 Ibid., 18.

113 We read there: "you will be for me a kingdom of priests וגוי קדוש and a holy nation." 
abstract separation of the seeds. Neither do I find in Jub. 16:17-18 any indication that "This passage sets the rhetorical stage for repeated warnings against the intermingling of seeds that ought to be kept distinct and the consequent profanation of the holy seed."114 The term "seed" appears many times in this short passage, but Hayes' assumption that it refers to the seed as opposed to children or descendants is definitely flawed, as I shall now show. To quote the relevant text:

And (that) all the seed of his sons should be Gentiles, and be reckoned with the Gentiles; but from the sons of Isaac one should become a holy seed, and should not be reckoned among the Gentiles. For he should become the portion of the Most High, and all his seed had fallen into the possession of God, that it should be unto the LoRD a people for (His) possession above all nations and that it should become a kingdom and priests and a holy nation ( Jub.16:17-18).

To apprehend literally the term זרע as seed in this passage would constitute a bizarre premise. From a logical and physical point of view, how could "holy seed" be engendered from one of Isaac's sons (Gen 21:12) and "unholy seed" from another? The sentence "and should not be reckoned among the Gentiles," interpreted by Hayes as referring to seed, is the verbatim translation of Num 23:9b, which relates to "a people dwelling alone, and not counting itself among the nations," not to the abstract seed. The subsequent phrase: "and all his seed had fallen into the possession of God, that it should be unto the LORD a people for (His) possession above all nations and that it should become a kingdom and priests," founded on Exod 19:5b-6a, must be interpreted as relating to the people. Hayes' literal perception of seed in Jub. 16:17-18 would mean that God is now in possession of Isaac's seed, a grotesque assertion. Hayes, however, זרע seems unconvinced that one cannot literally interpret the Hebrew term plausibly used in the original text and in other similar cases as seed, but rather one must interpret it as descendants or people. She persists in her determination to understand the term "seed" literally, despite the author/translator's clear indication that he intends that the people — not the seed—should be God's possession, and the biblical source of the sentence also relates to people. Jubilees discerns between the Israelite man who marries a foreign woman and the one who gives his daughter or sister in marriage to an alien man. Only the latter is punished by stoning, since his action is considered as having "given of his seed to Moloch." This biblical citation refers in its straightforward and

114 Hayes, “Intermarriage and Impurity," 19. 
habitual meaning to the strict prohibition of concretely offering one's children to the Moloch idol; the rabbinic writings and traditional commentators interpreted it in the same way. The author of Jubilees, as it seems, interpreted the phrase metaphorically, intending it as giving in marriage one's daughter to an alien idol worshipper. ${ }^{15} \mathrm{His}$ comparison of marrying one's daughter to an alien to giving one's children to the idol, and his consequent declaration of the punishment of stoning, the most severe type of execution, can only be understood and justified by the following logical consideration. Since the daughter will ultimately adopt the religion and customs of the foreign husband's people, as was typically the consequence, giving her in marriage to an alien is like giving one's descendants to be burned as worship to the idol. This clearly indicates that the author's motive for applying such harsh punishment as a deterrent against giving one's daughter in marriage to an alien was the survival of the Israelite people and their particular faith and culture.

Therefore, Jubilees perceives giving a daughter in marriage to an alien as a much greater sin than the marriage of an Israelite man with a foreign woman: since the latter action does not endanger Israel's survival, it cannot be compared to giving one's offspring to Moloch, and consequently does not justify capital punishment. ${ }^{116}$ On the other hand, Hayes' argument that the prohibition of mixing the seed is Jubilees' motive does not support the comparison to giving a child to the Moloch, since the woman has no seed, and capital punishment cannot therefore be justified. ${ }^{117}$ Further, there is no logical justification according to Hayes' theory for the distinction between the punishments promulgated by Jubilees for intermarriage of an Israelite man with an alien woman, and of an Israelite woman with an alien man, since in both cases there would be a mixing of seeds. However, here too, Hayes claims that Jubilees imposes stoning on both cases, since according to her theory the defilement of the "holy seed" is equal, ignoring the clear, conflicting texts of vv. 7 and 10-11,

115 M. Meg. 4:9 criticizes an interpretation prohibiting sexual relation with a Gentile woman, giving her your seed. Mixing the seed, however, was not the issue.

116 Shaye Cohen, "Conversion to Judaism in Historical Perspective: From Biblical Israel to Postbiblical Judaism," Conservative Judaism, 36, 4 (1983) 31-45, at 38 writes that Jubilees "bitterly denounces intermarriage," but "giving one's daughter to a Gentile is a much greater sin in this author's [Jubilees'] eyes than is the taking of a Gentile's daughter." Werman, "Jubilees 30," 13 likewise understands that the comparison to giving one's child to the Moloch relates only to the marriage of a Jewish woman to a Gentile man.

117 Hayes, "Intermarriage and Impurity," 16 admits that "in reality no one biblical verse in isolation expresses the prohibition as formulated by Jubilees." Only "a complex concatenation of several biblical verses," chosen and interpreted according to her preconceptions, leads to her conclusion. 
which decree the stoning only to the man marrying his daughter to a foreigner. ${ }^{118}$ Hayes' attempt to linkJubilees' rules against intermarriage to Ezra's regulations ${ }^{119}$ demonstrates the fallibility of her holy seed thesis; Ezra does not decree capital punishment for the men who married foreign women, as Hayes alleges that Jubilees established for such transgressions. ${ }^{120}$

Further, Jub. 30:7-10 decrees the stoning of the father who gave his daughter or sister to "any man who is of the seed of the Gentiles... for he hath wrought shame in Israel." The father is thus accused of having defiled the holy people of Israel, ${ }^{121}$ giving his daughter to the Moloch, but the Gentile man is not likewise accused of defiling his daughter; the mixing of seed is not the issue here. ${ }^{122} \mathrm{We}$ read further: "and they shall burn the woman with fire, because she has dishonoured the name of the house of her father, and she shall be rooted out of Israel." The woman too is accused of having defiled "the house of her father", not the seed of Israel or the people of Israel.

חרפה a Jacob's sons, Jubilees' model similarly perceives Shechem's action as "shame" (Gen 34:14), not a defilement.123 The character of their justification before Jacob of their action (Gen 34:31) equally indicates the protection of Dinah's honour as their motive, not a punishment for having defiled her.

I likewise dispute Hayes' statement that according to Jubilees, "sexual intercourse with a Gentile...jeopardizes the continued existence of the entire community on God's land,"124 founded on its understanding of Lev 18:28 and 20:22. However, in both chapters sexual intercourse with a Gentile does not appear in the long list of sexual misbehaviours indicated as inducing their vomiting out of the land. Similarly, her superlative affirmation is not hinted at in Jubilees. We read there in 30:15b: "the whole nation together be judged for

118 We read in 30:7: "And if there is any man who wishes in Israel to give his daughter or his sister to any man who is of the seed of the Gentiles he shall surely die, and they shall stone him with stones;" and in v. 10: "the man who has defiled his daughter shall be rooted out in the midst of all Israel, because he has given of his seed to Moloch."

119 Hayes, "Intermarriage and Impurity," 39 writes: "and especially Ezra."

120 Ezra 9:12 prohibited both types of intermarriage, comparing all foreigners to the biblical rule against intermarriage with the Canaanites (Deut 7:3-4), but does not establish punishments for its transgression, except their separation.

121 Charles translates Jub. 30:8b: "for Israel is holy unto the LoRD, and every man who has defiled (it) shall surely die."

122 It is evident that the term מזרעו of Lev 20:2, the source of Jubilees' dictum, must be interpreted as denoting his children, not his seed.

123 Charles' interpretation "for that were a reproach unto us" (Jub. 30:13) does not represent the correct translation of the biblical text to which it surely relates.

124 Hayes, "Intermarriage and Impurity," 18. 
all the uncleanness and profanation of this man"; while the entire nation may be judged, and possibly punished, there is no threat to its continued existence. I agree with Hayes' statement about the threat to Israel's continued existence as recorded in Ezra, but the nature of the threat is the danger of assimilation by the surrounding foreign nations through intersocialization, rather than defilement of the holy seed.

\subsubsection{Concluding Reflections}

I believe I have rebutted Hayes' theory of the mixing of holy Israelite seed with unholy Gentile seed as Ezra's motivation for prohibiting intermarriage with all foreigners, and demonstrated the flaws in all her presumed supporting evidence from different sources. Finally, having concluded my debate against her theory, let me reflect about a general consideration. The indiscriminate use by Jubilees' author of a variety of distinct concepts such as shame, uncleanness, abomination, defilement and profanation in the portrayal of the Dinah narrative demonstrates the futility of deducing philosophical or halakhic conclusions from this book, and likewise with other similar writings. Moreover, the author of Jubilees did not have in mind Hayes' or my conjectures about the motive of the intermarriage prohibition, and we do not know precisely the terms he used in his original Hebrew version. His changes in crucial details of the biblical narratives were motivated, not by his intention to classify the type of transgression of intermarriage, but by his aspiration to blot out the impression of any wrongdoing by Simeon and Levi and on the contrary to laud their act, and to justify his imposition of capital punishment for giving one's daughter in marriage to a Gentile man by comparing it to giving a child to Moloch, as decreed in Lev. 20:2.

\subsection{Disputing Hayes on Qumran's Attitude towards Intermarriage}

I shall now turn to Hayes' interpretation of the authentic Qumranic document 4QMMT, with which she aims to support her theory of Ezra's "holy seed" motivation for his comprehensive intermarriage prohibition by demonstrating the identical principle in Qumran texts. I shall therefore critically scrutinize Hayes' supporting quotations and interpretations, which I believe are inappropriately used or else adjusted to fit the substantiation of her theory. In her quotation of 4Q396 (4QMMTc) IV:4-11, for example, she adds the term "seed" in her interpretation of והמה בני קדש (vv. 4-5) "being sons of the holy [seed],"125

125 Hayes, “Intermarriage and Impurity," 26. 
versus the translators' literal "they are (members of) holiness." Hayes indeed puts the term in brackets, like many other restructured texts in this document, but the term "seed" is not such a reconstruction: seemingly, it could not originally have been mentioned there. The term זרע "seed" appears only in v. 10, relating solely to the priestly seed, criticizing its mixture with Israelite seed, a concept utterly opposed to Hayes' theory of equalizing the holiness of the Israelite and priestly seeds. The insertion of "seed" in the text is thus inappropriate and in conflict with a straightforward reading of the Qumran texts, similarly to Hayes' interpretations of biblical and post-biblical texts, as demonstrated above, and presumably motivated by an urge to prove her theory by any means.

4Q396 (4QMMTc) IV:4-11, commonly interpreted as referring to marriages of priests with Israelite women, is interpreted by Hayes as relating to Israelites marrying Gentiles, since "Holy Israel" is written in v. 5; hence, according to Hayes, the contamination of holy seed must refer to contamination of ordinary Israelites. ${ }^{126}$ She ignores, however, the rationale for the term טמא, "they defile the holy seed," interpreted by her as "contamination;" this rationale appears only in v. 10, unquestionably referring to priests, after the accusation in v. 9: "that a part of the priests and of the [people mingle] [and] th[ey ]unite with each other and defile the [holy] seed." In fact, the entire lemma vv. 4-11 constitutes one unit, referring to one single topic: the intermarriage of priests with Israelite women. Indeed, vv. 5-7, which seemingly interrupt the literary flow of the lemma, simply provide the legal basis for their claim that intermarriage of priests with Israelite laics is similarly prohibited as kilayim, because the Israelites are holy, but the priests are the holiest of the holy (v. 8). This justification, the core of the lemma, cannot be attributed to intermarriage of Israelites with foreign women. Hayes' claim that the term העם in v. 4 relates to the "people," and thus supports her theory that the zenut - the marriage of Israelites to foreigners-is condemned, is equally incorrect. The term is qualified by the preposition בתוך העם (literally) "in the midst of the people," and, as I understand also from the context, means "spread among the people" - an expression including the entire people, Israelites and priests, but no foreigners. We observe that, at the separate mention of priests and people, in v. 9, the term is written:הכהנים והעם with the conjunction "and," intending two separate and distinct entities "in the midst of the people." Thus, her claim that the zenut refers to the marriage of Israelites to foreigners is unwarranted, also because its nature, namely intermarriage with foreigners, is not mentioned, whereas intermarriage between priests and Israelites is explicitly identified.

126 Ibid., 27. 
ימטמאי [ם ]את זרע [ הקודש ואף] את 11-10. The heavily reconstructed vv. (זרע] עם הזוjוi could be interpreted, as Hayes claims, as being that the second phrase relates to Israelites, but we do not know definitely the exact original text, nor the missing words between $\mathrm{v} 10$ and 11; its rationale, which plausibly followed the subordinate conjunction כי "because," regrettably is lost. Hence, it cannot serve as supporting a supposed/visionary interpretation that has no endorsement from another explicit source. On the other hand, ${ }_{11}{ }_{19}$ (11QTemple ${ }^{a}$ LXIII:10-15 acknowledges the biblical permission to marry a foreign captive woman, and one must assume that their offspring are perceived as Jewish: while the lemma decrees a seven-year waiting period for permission to eat sacred offerings and touch pure food, intercourse is permitted after one month according to the biblical rule, and hence any children must have been understood to be legal Jews, not a defiled entity of mixed holy and unholy seed. Hayes, aware of this rule, patently contradicting her theory, dodges it by devising a scheme that it does not include Canaanite women, without any scriptural or Ts hint of such a restriction. ${ }^{127}$ See our disputing arguments to this claim on page 326 .

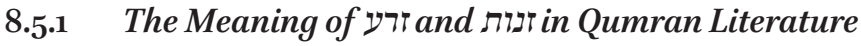

Having explored the different meanings of the term זרע in Scripture, I shall now do the same regarding its use in Qumran literature, indicating where the term must be perceived as meaning the people, descendants, or offspring, but not "seed." I did not find any use of the term that must be interpreted as seed, except those referring to actual seeds of plants in $4 \mathrm{Q}_{3} 67(4 \mathrm{QRP})$ and of man in 4Q274 (4QTohorotA). ${ }^{128}$ Conversely, I will cite some of those verses in Qumran writings (including citations from Jubilees) that must be interpreted as people/ offspring or as descendants; the remaining instances can be interpreted in either way. For example: "If the זרע ישראל people of Israel lives according to this law" in CD XII:21-22; "But [דרע האד] the offspring of ma[n] kind has not

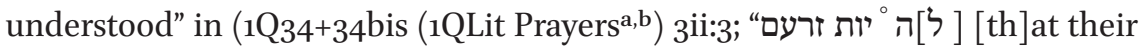
offspring might be in Your presence forever" in 1QHa IV:14; ופרות זרע "מרע "and mul-

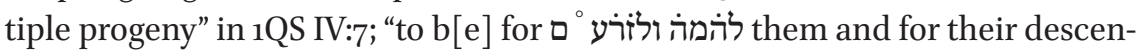
dants" in 4Q158 (4QBibPar [4QRPa]) 4:7-8; "and זר ע בניכה ] the descen]dants of your children" in 4Q158 (4QBibPar [4QRPa]) 14:6-7; "And the nations shall [not] work with the בזר] ישראל with children of Israel" in 4Q159 (4QOrdina)

\footnotetext{
127 Ibid., 8.

128 The phrase ומזרע הקד [ושי[i in 11Q11 (11QapocrPs) V:6-8 cannot serve as contrary evidence since it is an element in an esoteric ritual of exorcism, a reference that has no implications for its regular use.
} 
2-4+8:2; "And to them will belong all the inheritance of Adam and to

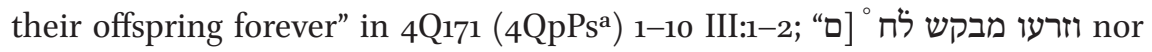

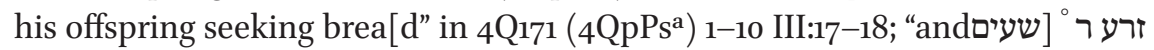
he offspring of the wi[cked are cut off," in 4Q171 (4QpPsa) 1-10 IV:1; "And he chose בזרע יעקוב the descendants of Jacob" in 4Q216 (4QJuba) VII:11; "[and cut you off ] ואת זרעד "וand your offspring [from benea] th the sky" in 4Q221 (4QJub 1:3; "יהיה רעכה so will be your offspring, unable to be counted" in 4Q225 (4QpsJuba) 2i:6-7; "[the dwelling of לכוב ל ז רע ישראל of al]l the offspring of [Israel" in 4Q266 (4QD) 9iii:11-12; "לזרעם to their descendants you gave your truthful statutes" in 4Q266 (4QDa) 11:11; "an eternal law for them ולזרעמה and their offspring" in 11Q20 (11QTempleb) V:10i, 11:4. Hence, Hayes' claim that the term זרע in Qumran writings should be understood as seed has no substantiation; in contrast, the above evidence disputes it.

Hayes grants great significance to the term zenut for the substantiation of her thesis, and possibly also of her association of the term with the prohibition of the "priestly/lay intermarriage," as she interprets 4Q396 (4QMMTc).

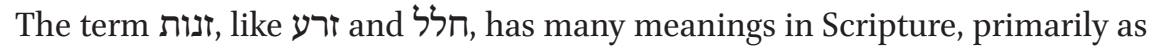
wrongfully leaving God, prostitution, and by association "wicked deeds."

The term intending betraying/rejecting God appears in Exod 34:15-16; Lev 20:5; Deut 31:16; Judg 2:17; 8:27, 33; and Ezek 6:9. It appears further with the same meaning in the metaphoric term "prostitute." I postulate that in Qumran writings some instances of the term must be interpreted as "wicked deeds," as in Scripture, while others that are associated with sexual misconduct can be understood as sexual transgressions, although this is not absolutely required since sexual misconduct is included in the generic meaning of "wicked/wrongful" acts. For example, the phrases מעוון הזנות (4Q225 (4QpsJuba) 1:1 translated as "guilt of immorality," but also בדרכי זונות cD VIII:5 and CD XIX, translated as "customs of fornication," should be interpreted rather as "wrongful ways/

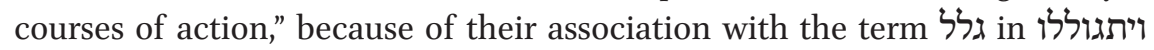
ללכת אחרי that intends idolatry, as we encounter the same copula בדרכי זונות "going after idols" in 1 Kgs 21:26, and the context—the antecedent and succeeding wicked deeds, such as traitorous practices, filthy lucre, bearing a grudge against one's brother, hating one's fellow, keeping away from nearest kin-comprises delinquencies that have no connection to sexual misconduct.

The same applies to the phrase ברוח זנות in 1QS IV:10 that has the same meaning in relation to its context, which mentions hypocrisy, want of self-control, foolishness, arrogance, abominable deeds, fashioned by whorish desires. The phrases ועיני זנות 1QS I:6 and similar in CD II:16 should also be interpreted as a generic expression of desiring wickedness, like the phrase זנות עינים in $4 \mathrm{Q} 436$ (4QBarkhi Nafshic) ) ii:: "the urge of the eyes[for evil things] you have 
removed from me." The translation "adulterousness" is in my opinion incorrect in the context. The author advocates the removal of the generic urge for wickedness and its substitution with "[the spirit of ho]liness you have set in my heart." The translation of the terms זנות as "fornication" in 4Q513 (4Q Ordinb) 2 ii 2 and 5 in the DSSEL is patently wrong; it is explicitly associated with מאכ" ליהם "eating forbidden food." Two different grammatical variations of the term in 4Q169 (4QpNah) 3-4ii:7-8 refer literally to a harlot, but are pronounced as the metaphor for all that is wrong. In fact, I do not disagree with Hayes that in some occurrences the term זנה intends some sexual misdeed, but I dispute her assertion that, like the terms מעל זרע זרע , it always has the same meaning of "seed" and "sacrilege."129 In fact, the philological root of the term is not clear; its root may have been "abandon/forsake," and it is mainly used in Scripture in that sense. The meaning of "prostitute" is probably an extension; since she is not loyal to the man she sleeps with, but abandons him and goes with another. ${ }^{130}$ Its root from זr "species/gene" (associated with sex) is another possibility, but then again as an extension, not as its primary and only meaning, as claimed by Hayes.

Christian Frevel and Benedikt J. Conczorowski build on the identical and in my opinion inaccurate interpretation of the term זנות a complex theory to demonstrate that "a purity-based pattern was added to the Deuteronomistic 'religious' pattern."131 For the substantiation of this theory, the lemma on Lev 20:1-5 in which the term appears (v. 5), they assert that it relates to a "mixed marriage," and as such defiles the sanctuary. This assertion is substantiated in a note on the basis of Jub. 30:10 that interprets it as relating to giving one's daughter in marriage to an alien man. Strangely, they overlooked the straightforward meaning of the text and its contexts, and on the basis of a midrashic interpretation of Jubilees, founded on heavenly tablets, claim that Scripture

129 John Kampen, "The Matthean Divorce Texts Reexamined," in New Qumran Texts and Studies: Proceedings of the Fist meeting of the International Organization for Qumran Studies, Paris 1992 (ed. George J. Brooke with Florentíno García Martínez, Leiden: Brill, 1994) 149-167, at 161 writes: "We can only conclude that is one of a few major terms employed for the purpose of defining activities contrary to the sectarian lifestyle elaborated in the various compositions, most frequently referring to the issue of marriage and sexual relations."

130 This root seems to be substantiated by the use of the term in Judg 19:2, in which case it is appropriate in the context: "she left him."

131 Christian Frevel and Benedikt J. Conczorowski, "Deepening the Water: First Steps to a Diachronic Approach on Intermarriage in the Hebrew Bible," Mixed Marriages, 15-45, at $3^{8-39 .}$ 
indeed relates to a mixed marriage. ${ }^{132}$ As a result of the same mistaken interpretation of the term they similarly make out the Phinehas narrative of Num 25:1-5 to add "a purity-based pattern" to the deuteromomistic prohibition of intermarriage (which in fact was based on a religious motive, namely the concern of leading to apostasy), creating a complex mixed and undefined concept thereby. The Phinehas narrative does not offer any hint that it relates to intermarriage; the term לזנות v. 1 must be interpreted here as "prostituting,"133 not marrying, since in v. 2 they invited the people, not their husbands, to sacrifice to their gods. In Exod 34:16 marriage is portrayed with the habitual term and the worship of idols is portrayed with the term used for evil deeds including sexual misconduct, when not followed by its specific character. ${ }^{134}$

Then, on the basis of their presumptions, Frevel and Conczorowski attempt to impose on Nehemiah a theory that "mixed marriages turn into a crucial danger when the society's core is constituted by the sanctuary," asserting that this argument is "in the background of Neh 13:28-29." Close attention to these verses in context, however, reveals no such "background." Nehemiah's dramatic intervention against the intermarriage with foreign women, from its beginning in 13:23 to v. 29 , is exclusively driven by a "religious pattern," namely the danger of apostasy, as forcefully portrayed by the example of King Solomon, and has no association with the sanctuary. In v. 28 at the conclusion of this topic of intermarriages, he boasts that he has even driven away one of the sons of the high priest, because he married the daughter of Sanballat the Horonite, an alien and Nehemiah's great enemy. On the basis of this last daring act he concludes his achievements regarding the elimination of intermarriage, but does not mention the purity of the sanctuary; he pleads to God to remember his good deed by driving out those priests and Levites because "they defiled the priestly office and the covenant of the priesthood." An issue of sanctuary purity, such as Frevel and Conczorowski allege, does not seem to be in the cards here or in Ezra 9-10.

\subsubsection{The Meaning of מעל in Qumran Literature}

The interpretation of the term מעל in Qumran writings is similar to that in Scripture. Among the thirty-some occurrences in these writings, there are none that must be interpreted as referring to sacrilege; five occurrences could be interpreted in either way, that is, breach of trust or sacrilege, because of the lacunae in the texts that do not permit us to ascertain with which matter

\footnotetext{
132 See section 8.4.6, on this topic.

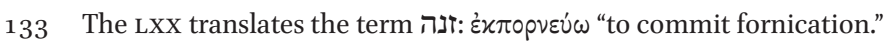

134 Tg. Onq. translates here the term ויטעין: ומוזנו "to make them err/to lead astray."
} 
the term is associated. I shall cite a number of occurrences of the term מעל that must be interpreted as breach of trust/treachery: (CD IX:16-17), (CD XV:13), (4Q166 (4QpHos ${ }^{\mathrm{a}}$ ) i:9), (4Q299 (4QMyst $\left.{ }^{\mathrm{a}}\right)$ 7:5-6), (4Q378 (4QapocrJosh ${ }^{\mathrm{a}}$ ) 3i:78), (4Q387 (4QapocrJer $\mathrm{C}^{\mathrm{b}}$ ) 2ii:3) and (4Q418 (4QInstrd ${ }^{\mathrm{d}}$ ) 101ii:5).

The phrase וכל המעל אשר ימעל 4n 4251 (4QHalakha A) 16:3-4: should also be perceived as unfaithfulness (as translated by Martínez and Tigchelaar), because of its context, but I have classified it among those that could be interpreted as sacrilege, granting more significance to the term לאכול, which appears in the verse, than to the subsequent term תועבה, which has no association with sacrilege since it represents idols. The same applies to מעלו אשר מעלה in (4Q30o (4QMyst $\left.{ }^{\mathrm{b}}\right)$ 2ii:4), which I believe (as does the translator) to represent breach of faith in this context, although I concede that taken in good faith, without considering the context, it could be interpreted differently.

Hayes, however, claims that the interpretation of the term מעל as "sacrilege" in 4Q397 (4QMMTd) IV: 4 is "the more ordinary translation," although she acknowledges that Qimron and Strugnell translated it as "treachery."135 On that basis, passing over the long list of divergent interpretations of this term, she continues to affirm that "the association of women and sacrilege is a clear appropriation of the language of Ezra" and that the author of 4Q397 thus evokes the "holy seed reasoning as the basis for its condemnation of intermarriage."136 Since, however, the author founded his declaration on the biblical verse Deut 7:26: "do not bring תועבה a detestable thing into your house," which plainly relates to idols, Hayes writes: "It appears that the prohibition against bringing an idol (to'ebah) into the home is interpreted by the author of MMT 4 Q397 IV:6 as a prohibition against bringing an idolatress or foreign women into one's home as a wife."137 To postulate such an interpretation against the simple, conventional meaning of the biblical verse, Hayes plausibly avails herself of the term ${ }^{2},{ }_{138}$ appearing in the antecedent verse, together with violence as one of the motives leading to destruction. However the term Iנות again has many meanings, and the context in this case does not support Hayes' supposition. It seems that she was aware of the flaw of her interpretation, and attempted to

\footnotetext{
135 Hayes, "Intermarriage and Impurity," 30. Martínez and Tigchelaar, DSSEL interpreted it as "disloyal."

136 Ibid.

137 Ibid., 31.

138 Ibid., at 17 she writes: "an Israelite woman who commits this zenut (illegal marriage) will be subject to death by burning because of the profanation incurred." This punishment, however, appears only in Jubilees, and we have no indication that Qumran concurs with it.
} 
correct it by adding a second interpretation "a foreign woman," but this has no association with the term to 'ebah appearing in the verse.

Hayes further attempts to prove her case from the phrase ומלבוא ע[מהם ]ללב אלה 4Q397 IV:8, "from associating wi[th them ]in these things and you k[now that there is not]to be found in our action מעל ושקר ורעה disloyalty or deceit or evil." The phrase לגב אלה has no parallel in Scripture or in Qumran writings, and therefore, Hayes asks, "What might the expression mean?" Despite relying on Qimron and Strugnell's suggestion that "it occurs in Mishnaic Hebrew in contexts of mixing pure food," she criticizes them, alleging that "What they fail to observe is that the context in which the preposition occurs in $m$. Yebamot 1.4 is equally concerned with intermarriage between groups with different purity standards." ${ }^{139}$ In the same vein, I would remark that she has misunderstood or misinterpreted this mishna, and that Qimron and Strugnell were correct in their assertion. The aim of the above mishna is to attest a high standard of behaviour on the part of the Houses of Hillel and Shammai. Their halakhic disagreements did not provoke personal friction between them: they intermarried, despite opposing halakhot regarding marriage issues, and likewise they borrowed vessels from one another, despite the opposing halakhot regarding pollution and purity of food and vessels. Neither of the two displayed topics is "concerned with intermarriage between groups with different purity standards," as Hayes claims. The marriage disputes refer to issues associated with the levirate rules, ${ }^{140}$ while the purity topic, in which the peculiar phrase appears, relates to purity of vessels; they are two distinct topics, but Hayes combines them to argue for another incorrect interpretation of $4 Q_{397}$ IV:8, contrary to its clear and logical meaning as concurring with the context: "from associating wi[th them ]in these things," as translated in the DSSEL.

Finally, if indeed Qumran perceived marriage between an Israelite man and a foreign woman to be a sacrilege by mixing the holy seed, as Hayes claims, one must wonder why we do not encounter an explanation or justification for David's marriage with the foreign Maacah, the daughter of the King of Geshur (2 Sam 3:3b), like that regarding his marriages with more than one woman in CD V:1-3.

Hannah Harrington, following in Hayes' footsteps, does not discern between the concrete and abstract concepts of the term טמא and the various meanings

139 Hayes, "Intermarriage and Impurity," 32.

140 B. Yeb. 14b and the commentators explain that they informed each other of such cases of disputes, and in such occurrences they avoided intermarriage, because the consequences were critical; in some cases the woman was perceived by one group as a married woman, and by others as unmarried. 
of the terms תועבה and in Scripture and consequently in Ezra/ Nehemiah, and perceives all to mean sacrilege. ${ }^{141} \mathrm{Her}$ linkage of the ill-defined term ערב in $4 \mathrm{Q}_{271}\left(4 \mathrm{QD}^{\mathrm{f}}\right)$ 5i:1-2, associated with forbidden work on the Sabbath, and in 4Q396 (4QMMTc) I:5 II:1-2, associated with blind people, with the term והתערבו in Ezra 9:2 to prove that intermarriage is a sacrilege, seems to me an association of apples with oranges. The term ערב has many meanings in Scripture, and also in Qumran writings; for example, in 4Q416 (4QInstr ${ }^{b}$ ) and $4 \mathrm{Q} 417\left(4 \mathrm{Q}\right.$ Instrc $\left.{ }^{\mathrm{c}}\right)$ it is associated with inheritance, but never in connection with marriage; see our interpretation of Ezra 9:2 on page 321.

\subsubsection{Disputing Hayes' Interpretation of the Phinehas Narrative}

Last but not least, Hayes attempts to substantiate her thesis from 1 Macc 2:4955, "where Abraham is explicitly coupled with Phineas in connection with zeal for the law." I do not see this in the text; Mattathias speaks to his children, asking them to "be ye zealous for the law," and to remember "what acts our fathers did in their time," but does not say that they were zealous; he attributed to each of them different virtues, and did not try to "couple" them in any particular common virtue. Only Phinehas and Elijah are mentioned with the attribute of zeal, not Abraham, which Hayes "couples" with Phinehas. Further, their "zeal" relates exclusively to their fight against idolatry in Israel, as is evident from Num 25:2, 3, 11, and 13, and has nothing in common with preventing the preservation of Israel's seed, as Hayes claims, uniting them instead in their zeal to preserve Israel's "seed." 142 God's anger was kindled because of Israel's worshiping the Baal Peor, not because of the whoring of Israel with the Moabite women. In this narrative, the Numbers' author exclusively uses the typical term קנא as in Exod 34:14 The divine jealousy to the worship of other gods, not to the Israelites' "whoring with the daughters of Moab" (Num 25:1), as in Hayes' imagination.

Phinehas, in his act, בקנאו את קנאתי really fought God's jealousy, like Elijah, who used the phrase: קנא קנאתי "I have been very jealous for the LORD” (1 Kgs 19:10). Phinehas was awarded perpetual priesthood for his "jealousy" for God; the Moabite women were only an accessory to the idolatrous worship, and are not mentioned, even in lauding him for killing the Midianite woman. ${ }^{143}$ Hayes,

141 Hannah Harrington, "Intermarriage in Qumran Texts: The Legacy of Ezra-Nehemiah," Mixed Marriages, 251-279, at 259-61.

142 Hayes, "Intermarriage and Impurity," 24, n. 68.

143 The text of Num 31:16, "They were the ones who followed Balaam's advice and enticed the Israelites to be unfaithful to the LORD in the Peor incident," accusing the Midianite women instead of the Moabites as appears in Num 25:1-2, indicates the incompatibility of 
however writes "Phineas' zealous defense of the holy seed against the incursions of Gentile fornicators is reckoned as righteousness"; despite great effort I have been unable to detect in the Phinehas narrative "his defense of the holy seed" or being "reckoned as righteousness." I did retrieve the reward to be "reckoned as righteousness" suggested by Hayes, but in reference to Abraham, as appears in Gen 15:6. In my text, Phinehas was awarded eternal priesthood, demonstrating a distinction between Abraham and Phinehas regarding deed and reward. It seems that Hayes' linking them creates a total fusion of both, and thus a fantastic portrayal of them in which Abraham, who married a Gentile woman, became the defender of the holy seed - a pinnacle of ignoring contrary texts and facts in order to prove a preconceived and highly speculative thesis - while Phinehas is reckoned as righteous, an attribute of Abraham. The scriptural confusion between the Moabite women in Num 25:1 and Midianite women in 25:6, 15, and 18 and in Num 30:16 indicates the insignificance of the women in the cause of God's anger and in Phinehas' act, versus Phinehas' jealousy against idolatry, rewarded by eternal priesthood.

I suspect that Hayes founded her allegation about Abraham's involvement in a sexual issue because of the KJV translation of 1 Macc 2:52: "was not Abraham found faithful in temptation," but her erudition should have induced her to be skeptical about the correctness of this translation. Abraham was not tempted by anything; indeed, he was supremely tested in this regard through God's command to sacrifice Isaac (Gen 22:1). The LXX translates Abraham's virtue in Maccabees by the term $\pi \varepsilon i p \alpha ́ \zeta \omega$ "to make proof, a trial of." The author of Maccabees bundled together the biblical source of his statement- "he believed the LoRD, and He credited it to him as righteousness" (Gen 15:6) with his text of Gen 22, because Scripture perceives the test of Isaac's sacrifice as Abraham's most distinguished virtue in Israelite mythology. ${ }^{144}$ It is almost incomprehensible how Hayes, possessing considerable erudition, overlooked all of the above questions in using these arguments to support her theory of "a vigilant preservation of Israel's seed," tortuously deduced from these verses of Maccabees in her effort to substantiate an untenable preconception.

the two narratives, which has been observed by scholars and traditional commentators. At any rate, the women were only the intermediaries for the main mischief, the worship of idols, emphasized in both verses.

144 We read in $m$. Abot 5:3 that Abraham was tested by God with ten tests, and passed them all, to his great esteem. 


\subsubsection{Hayes' Interpretation and Ezra's Intentions}

In sum, I suspect that Hayes' interpretive thesis is founded on a rigid attitude of refusing to acknowledge that some scriptural terms can and must be understood in many ways according to context; for her, as we have seen, the term זרע always means "seed," מעל is always associated with "sacrilege," זנות with sexual mischief, and so on. The fact that in many instances (in some cases, an overwhelming majority) a term must be interpreted differently due to its context, does not seem to alter her immutable approach. I admire Hayes' willingness to undertake the Sisyphean chore of substantiating her theory of Ezra's decree, which is founded on the concept of the preservation of the Israelite "holy seed" on the basis of one inadequately researched phrase והתערבו זרע in Ezra 9:2, not pronounced by Ezra, the decree's legislator, all the while rigidly ignoring the significance of the context for the correct interpretation of crucial terms that demonstrate the opposite conclusion. Her tenacious effort to justify her primary misapprehension leads to building further questionable concepts on that shaky foundation, at times even against well-established contrary viewpoints. I have discussed a number of these terms, proffering plentiful examples (the various meanings of the term טמא in Scripture are reviewed in a separate Appendix to this chapter). There are, however, additional questions that, in my opinion, contradict her thesis of Ezra's motive for his extension of the intermarriage prohibition to all Gentiles.

Hayes uses in her article an array of expressions to portray the implications of a mixed marriage, such as: "the holy seed of Israel becomes intermingled with unconsecrated, or profane, seed" (p. 10); "the Israelites themselves are the objects of desecration" (p. 13); it constitutes a "profanation of the holy seed of the people Israel, a form of sacrilege" (p. 11); it "is zenut, a sin that generates a moral impurity, thus defiling the holy seed of Israel and indeed the entire house of Israel" (p. 21). Relying on her interpretation of Lev 18 and 20, she asserts that according to Ezra's theory sexual intercourse with a Gentile woman constitutes a transfer of seed with dire consequences: "(1) it defiles the parent, the land, the sanctuary, profanes God's name; (2) is punished by extirpation of the offender and his kin; and (3) jeopardizes the continued existence of the entire community on God's land."145 As a practical question relating to her theory, the intermixing of seeds is not an abstract occurrence; it represents a concrete fact, and I am asking how such "intermingling/intermixing" or "contamination" materializes, since only the man impregnates the wife with his seed; it cannot be mixed with any other seed, because according to the common belief in Ezra's period, the woman has no seed. There are also a great number of other

145 Hayes, "Intermarriage and Impurity," 17-18. 
practical questions about the status of the "transgressors" of the intermarriage prohibition, according to her theory, and the methods of redressing the iniquitous deeds. Specifically, how does it affect the Jewish men who married the foreign women, their offspring, the people as a whole and the possible remedies?

Scripture records only the defilement of the son of a priest with a prohibited woman, making his descendants ineligible to serve in the Temple; the son is called חלל (Lev 21:15), but the priest himself is not defiled. ${ }^{146}$ Scripture does not divulge to us the status of an Israelite who married a mamzer female or of their offspring. ${ }^{147}$ Hence, what is the status of someone who marries an alien woman? Since Hayes claims that intermarriage "defiles the parent," and "in Ezra 9:1-2 at least, it is clear that the Israelites themselves are the objects of desecration,"148 one must ask: does the desecration relate solely to the man who has married a foreign woman, or are all Israelites desecrated, as Hayes alleges, and in what does this desecration consist? Is he no longer considered an Israelite? Is an Israelite woman prohibited to marry him? She states further: "sexual union with a Gentile results in defilement and profanation of a variety of sancta but particularly the holy seed of Israel," of all Israelites, "since all Israel is holy" (p. 18). Would it result in his seed being profaned throughout posterity? And what would be the consequences of the profanation of his seed and of the sacrilege: would the profanation affect his future children with an Israelite woman, and what are the functional consequences of the incurred sacrilege? What are the practical and functional consequences of "the moral impurity [caused by intermarriage] that defiles the holy seed of Israel and indeed the entire house of Israel"? Who is affected by the "dire consequences for the seed of Israel," the seed of the transgressor or of all Israel; and what are the functional consequences? Ezra and Nehemiah do not divulge any information on these issues, and moreover it does not seem that their decree and its accomplishment had any additional adverse effect on the men who married the Gentile women beyond their separation from their wives and children. Hayes, as it seems, does not care to address these practical questions, crucial for comprehending the legal consequences of Ezra's belief and decree, as she perceives it.

\footnotetext{
146 B. Sotah 23 b confirms it.

147 As a consequence of the rabbinic permission to marry Ammonite and Moabite women (see pp. 305-308), the same rule should relate to marrying a mamzer woman, but applying a selective midrashic exegesis (see Heger, Cult as the Catalyst). b. Yeb. $7_{6 \mathrm{~b}}$ prohibits the marriage of an Israelite with a mamzer, male or female alike.
}

148 Hayes, "Intermarriage and Impurity," 12-13. 
Furthermore, the most intractable question is: what has Ezra achieved for the re-establishment of the holy seed of the transgressors and of Israel by the separation of the foreign women and their children? The mixing and profanation of the holy seed was a fait accompli at conception, and the separation of the women and children could not change it. Neither Ezra nor Nehemiah tell us what happened to the women and their children; were they driven out from the territory of Judah or did they remain there? As cited earlier, it does not seem that Ezra expelled the families whose Jewish identity was unproven from Judah; in the same way he could have left the children of intermarriage with their fathers. ${ }^{149}$ Further, were these latter children perceived as Jews, since according to the contemporary law they were legally Jews (as is evident from Ezra 2:59-6o and Nehemiah 7:61-62, as demonstrated above) ${ }^{150}$ or were they perceived as Gentiles, despite being born from the Israelite "holy seed" of their fathers? I would hypothesize that the male children were circumcised, since they were born in an Israelite family from the seed of a Jewish father, and the Jews were commanded to circumcise every male of their household, including slaves (Gen 17:12-13). The leaders who raised the issue of the intermarriage before Ezra would certainly have complained acrimoniously about a failure to accomplish the most significant divine decree and sign of God's covenant with Israel, if they were not circumcised. To avoid further sinning by future sexual intercourse with the foreign women, Ezra could have ordered separation from the women, but not from the children, keeping them with their fathers. That could have made the separation less painful, even if the children were perceived as Gentiles, and could have ensured better chances for a successful fulfillment of the decree. How did expelling the children rehabilitate those affected by the intermarriages and the resulting conceptions, which occurred through "sexual intercourse with a Gentile," as Hayes claims?151 Their contaminated, desecrated, "alloyed and tainted mixed seed," according to Hayes, ${ }^{152}$

149 Many different terms are used in Ezra and Nehemiah to portray separation/expulsion/ banishment, such as: ויבדילו , ואבריחהו מעלי in Neh 13:28 13:3, ואשליכה in Neh 13:8, הבדלו in Ezra 10:11, but none of these terms offers us an exact indication as to what happened to the women and their children.

150 Shaye J.D. Cohen, The beginnings of Jewishness: Boundaries, varieties, uncertainties (Berkeley, CA: University of California Press, 1999) at 273 states, "The matrilineal principle was not yet known in second-temple times," and "The matrilineal principle is first attested in the Mishna." Hence, the offspring of a Jewish father were considered Jewish regardless of the mother's ethnicity. See also Heger, "Patrilineal or Matrilineal," 224-230 on this issue.

151 Hayes, "Intermarriage and Impurity," 17-18. See above, p. 350.

$15^{2}$ In fact, at ibid. ${ }_{13}$ Hayes asserts that the "desire to preserve the seed of Israel unalloyed and untainted" expressed by Tobit's author corresponded to "Ezran terms." 
could definitely not be separated, and their expulsion could not retroactively reinstate the holy-seed status of their fathers and/or the land, or reverse the profanation of God's name caused by consummated sexual intercourse with a Gentile woman. ${ }^{153}$ Repentance and ceasing such intercourse could, according to Jewish theology, reinstate the holy status of the Israelites, but the physical separation from their children would have no effect on that restoration. The fact that Ezra and Nehemiah do not provide us with any information about all these questions, relevant to the theory of seed contamination, seems to me a clear indication that this theory was not in their mind, and the prohibition of intermarriage was instead induced by their effort to prevent acculturation with the surrounding nations, the source of the Gentile women - they declare this explicitly—and thus coincides with the texts of Deut 7:3-4 and Exod 34:15-16. The expulsion of the foreign women and their offspring, and only this action, fully accomplished this goal.

\subsubsection{In Conclusion: Ezra's Prohibition in Relation to Divine Law}

Finally, Hayes' theory would attribute to Ezra a halakhic decision that would taint with grave transgressions all the great Israelite personalities-a list headed by Abraham and Moses themselves - who married Gentile women and thus by her interpretation intermixed the holy seed of Abraham's descendants. According to my thesis, however, neither Abraham nor Judah or Moses transgressed the law, since the decree prohibiting marriage with Canaanites comes into force only after the entrance of the Israelites into Canaan (Exod 34:12-16 and Deut $7: 1-6)$. This detail indicates that the concern of evil influence was the motive for the intermarriage prohibition, not the mixing of the seeds, which anyhow would have already occurred at Abraham's intercourse with Hagar, if indeed Ezra asserted that by intermarriage the Israelite זרע הקדש, literally the "holy seed" is defiled or profaned by its mixing with unholy seed, and thus loses its holiness, as Hayes suggests. Consequently, there would have been no logic in prohibiting intermarriage, since the holy seed would have been already mixed and defiled.

Ezra does not maintain that he introduced a new law, a prohibited deed, as Hayes alleges; the leaders accuse the people of having already mingled the holy "seed" before Ezra's intervention (Ezra 9:1-2); Ezra complains that the people have forsaken the commands of God given by the prophets (9:10-11), referring

153 S. Japhet, "The Expulsion," 141-161, at 143-144 draws attention to the fact that although Scripture forbids intermarriage with some nations, there is "no indication of the procedure that should be followed in the case of transgression." The expulsion of the women and their children has no "support of social precedents or legal considerations." 
to an ancient divine law, broken again (9:14). It is beyond question that he does not pretend to have introduced a new rationale ${ }^{154}$ or prohibition; he only argues that the original divine law prohibiting intermarriage with Canaanites was motivated by the necessity to avoid evil influence. Ezra merely extended it to include all Gentiles, because of the changed circumstances: the acute contemporary danger from the other foreign nations in the surroundings of Judah, all of whom practised idolatry. Thus, exactly corresponding conditions to those extant at the arrival of the Israelites in Canaan required Ezra's adjustment of the original decree. Ezra justified his decree and its motivation by referring to the intermarriage prohibition of Deut 7: הנשוב להפר מצותיך ולהתחתן בעמי "Shall we break your commandments again and intermarry with the peoples who practise these abominations (Ezra 9:14)?"

\subsection{Conversion and the "Holy Seed" Theory}

We do not know exactly when the institutionalized act of conversion was universally introduced in Israelite society, but it is evident that it was generally adopted in the rabbinic period and acknowledged by them, as Hayes confirms. ${ }^{155}$ Conversion is the antithesis of seed purity, and hence if her theory were correct, it would follow that the rabbis promulgated halakhic rules in blatant conflict with Ezra. That seems implausible, since Ezra was highly revered as the agent of the Torah's renaissance, ${ }^{156}$ unless they interpreted Ezra's text as I postulate it, and as is confirmed in b. Yeb. 23a's statement that the intermarriage prohibition of Deut 7 applies to all Gentiles: "for they will turn your sons away" (v. 4). The rabbis understood Ezra's extension of the intermarriage prohibition to all foreigners in terms of the same Deuteronomic motive for the prohibition of intermarrying with the Canaanites. Hayes, however, attempts to upset this clear and simple dictum by substituting for it a complex and vague cognitive construction; as Isa 40:4 puts it, "the uneven ground shall become level, and the rough places a plain." Hayes has not adequately considered the issues of the ethnic identity of the offspring of a marriage between a Jewish man and a Gentile/slave woman. This rule has no association with matrilineal descent or with concern about evil cultural influence, and according to the

154 Hayes, "Intermarriage and Impurity," 9.

155 Hayes, Gentile Impurities, 166 states, "the rabbis maintain that the marriage of a convert and an Israelite is permitted."

${ }_{15} 6$ We read in $t$. Sanh. 4:7: "Ezra merited that the Torah should have been given by him, if Moses would not have anticipated him." 
rabbis, in all permitted marriages the ethnicity of the offspring is established by that of the father. Only at prohibited marriages that do not allow a legal marriage agreement between the two partners, the basis of the Jewish marriage laws, is the ethnicity of the offspring established by the mother, since the father is legally unknown. That is the rabbinic philosophy, as I have demonstrated elsewhere. ${ }^{157}$ Similarly, one should wonder why Ezra would oppose the acceptance of foreigners who wanted to join the Israelite community, as Hayes alleges, in blatant conflict with the Second Temple prophet Zechariah's declaration: "Many nations will join themselves to the LORD on that day, and they will be my people" (Zech 2:11). ${ }^{158}$

In her relentless quest to prove her case, Hayes tries to demonstrate that indeed, Jubilees does not acknowledge conversion of Gentiles, because of the pollution of the holy seed. Analysing Jub. 30, which relates to the Dinah narrative and its aftermath, she claims that one may understand from the scriptural text that Hamor's "acceptance of this [circumcision] requirement satisfies the Israelites, and the marriage is to take place in due time,"159 but she then argues that the author of Jubilees maintains that there is "no way to contract marriage properly with a Gentile, even when the Gentile partner is willing to undergo circumcision and join the Israelite community." 160 I cannot agree with either her premise or her conclusion. The proposal of Jacob's sons to Hamor to circumcise was not a genuine offer or a serious consideration, but was from the beginning a plot to kill the Shechemite Royal family and their people, as is evident from Gen 34:13: "Jacob's sons replied deceitfully as they spoke to Shechem and his father Hamor"; thus, this incident does not reveal whether the author/ redactor of Genesis, or of Jubilees, permitted conversion of Gentiles or not, or whether it constituted a problem requiring a decision by Jacob's sons to accept them or not.

\subsubsection{Qumran and Converts}

Hayes' attempt to impose the holy seed theory on Qumran brings us to the topic of whether Qumran accepted converts or not. If they did so, they could not have accepted the holy seed theory, as indeed Hayes argues, stating: "Circumcision does not convert profane seed into holy seed, and thus miscegenation is forever and always zenut,"161 in an attempt to connect this principle

\footnotetext{
157 Heger, "Patrilineal or Matrilineal," 224-230.

$15^{8}$ See Maccoby, "Holiness and Purity," 166.

159 Hayes, "Intermarriage and Impurity," 21.

160 Ibid.

161 Ibid., 22.
} 
relating to Jubilees with 4 QMMT.162 Similarly, Schwartz writes that "Qumran texts show little interest in circumcision,"163 explaining that "no community [like Qumran] that ascribed such prestige and authority to priests qua descendants of Aaron could easily admit that differential birth might be overlooked or overcome by any commitment or operation." He builds his theory on the oddity that Jubilees, a "priestly book," retells Gen 34 without mentioning the circumcision of the Shechemites to legitimize their intermarriage with Jacob's family, at the suggestion of Jacob's sons." ${ }^{164}$ But as we have just seen, the circumcision offer cannot serve as evidence for a thesis for or against the conversion of Gentiles.

Moreover, Schwartz misses the fact that the author of Jubilees attempted in relating this story to portray Jacob's sons Simeon and Levi (particularly the latter) in a very positive light. Genesis does not tell us that Jacob was angry when he became aware of what had happened, nor that he was among those who spoke deceitfully with Shechem and Hamor, as Jubilees contends. Further, Jubilees maintains that Levi was chosen for the priesthood for his executing "righteousness and judgement and vengeance on all those who arose against Israel" (Jub. 30:18), whereas Jacob denounces them harshly for their deeds (Gen 49:5-7). In other words, the author of Jubilees altered the text and the spirit of the Dinah narrative to put all the blame on the Shechemites, while completely exonerating Simon and Levi. Using the sacred act of circumcision as a stratagem in a deceitful act, and killing circumcised people-converts to Judaism—could have been perceived as sinful and repulsive, and that may

\footnotetext{
162 Ibid.: "it resonates like passages in 4QMMT."

163 Daniel R. Schwartz, "Yannai and Pella, Josephus and Circumcision," DSD 18/3 (2011) 339359 at $35^{2}$.

164 Ibid., 356. Conczorowski, "All the same as Ezra?" at 100-101 also alleges that the intermarriage issue in Ezra's time was associated with the earlier intermarriage prohibition in Gen 34; I dispute this assumption. The indignation of Jacob's sons was unconnected with an intermarriage prohibition (Judah and Joseph married foreign women), but because of Shechem's נבלה insulting and humiliating action towards Dinah's family (Gen 34:7), treating her like a prostitute (as v. 31 explicitly states), The identical term נבלה for the portrayal of the repulsive act describes the rape of Tamar (2 Sam 13:12-13); the issue there was definitely unconnected with illegal sex, but rather with Amnon's loathsome behaviour. The term טמא has no "cultic connotations" as Conczorowski claims; neither has the term נבלה in Deut 22:21, to which he compares Gen 34; adultery is not a cultic transgression in Israel, nor in the surrounding cultures. See in the Appendix to this chapter the great variety of meanings of this term. See also a deliberation about the Dinah affair in Chapter 2 on pp. 92-94.
} 
have been the motive for its concealment. ${ }^{165}$ Such a hypothesis may demonstrate that Jubilee's author acknowledged conversion, and therefore attempted to absolve Simeon and Levi from the guilt of killing Jews.

It is curious that Schwartz does not quote the relevant Qumranic texts about their attitude towards proselytes in his deliberations about circumcision in Qumran. We read in CD XIV:3-6 that proselytes were included at the community's discussions; albeit they were the last, after the lay Israelites in their order of sitting and right of speech, they were nevertheless full members, as is entirely evident. On the other hand $4 \mathrm{Q} 174$ (4QFlor) seems to oppose CD XIV: "This (is) the house which these will not enter] [for] ever, nor an Ammonite, a Moabite, a bastard, בן נכר a foreigner, or a וגר proselyte forever, for his holy ones (are) there. [His glory shall] be revealed for[ev]er; it shall appear over it perpetually. And זרים strangers shall lay it waste no more, as they formerly laid waste."

Gudrun Holtz's viewpoint about this issue of the proselytes in Qumran is somehow confusing or not adequately focused. ${ }^{166}$ She writes: "The passages mentioned concerning the proselyte [CD VI:21, IX:2 and XII:10-11] indicate that the Community apparently was willing to accept ethnic non-Jews in their ranks," but in note 89 she seems to agree with Hayes that 4 QMMT "prohibits marriages between Jews and proselytes."167

\subsubsection{The Meanings of ger and ezrakh}

K. Berthelot offers an extensive study about the status of the גר "proselyte" in Qumran. ${ }^{168}$ After a short exposition about biblical passages regarding the ger and the problems of attempting to trace the biblical source of each of the Qumranic quotations about the ger, she perceives the term's different meanings as perhaps an issue of diachronic versus synchronic reading; that is, the result of an evolution in its meaning. It seems to me that Berthelot, following Rendtorff,, 169 perceives the term

\footnotetext{
165 A similar apologetic stance is pursued by Josephus in ANT. 1:337-340. For example, he contends that Dinah was raped, and conceals entirely the deceitful proposal of circumcision by Jacob's sons. Josephus conceals the Shechemites' circumcision, alleging that Simeon and Levi killed them in their sleep, after a great feast.

166 Gudrun Holtz, "Inclusivism at Qumran," DSD 16/1(2009) 22-54 at 45-6.

167 She erroneously adds that such a union "is also prohibited in rabbinic law," explicitly permitted to Israelites in m. Qidd. 4:1; such prohibition applies only to priests.

168 Katell Berthelot, "La Notion de גans les Texts de Qumrân," RevQ 19, 2 (2000) 171-216.

169 Rolf Rendtorff, "The 'ger' in the priestly laws of the Pentateuch," in Ethnicity and the Bible (ed. M.G. Brett; Leiden: Brill, 1996) 77-87.
} 
one perceived to be like an Israelite, ${ }^{170}$ a presumption I doubt, and an issue I will discuss later in my proposition, but this demonstrates the complexity of the topic. Berthelot also raises the question whether the ger can be perאיש אחר אחיהו appears the phrase אח in CD XIV:5, literally "[All four groups shall be mustered by their names] one after his brother," and comments that it may be understood as "one after the other," in the context, as the translators of the DSSEL indeed did, without any connotation of brother or metaphorically appertaining to the same people. Considering, however, that the citation CD VI:21-VII:1 "to grasp the hand of poor and needy vac and alien and to seek each the welfare of אחיהו his brother," Berthelot conjectures that the ger is also perceived as a "brother." In conclusion, she states that in the $\mathrm{CD}$ the ger seems to be the most strongly associated and integrated in Israel, but nevertheless remains a ger. ${ }^{171}$ In contrast to Hayes, Berthelot attempts to reveal the practical consequences of that hybrid status, acknowledging that we do not have any halakhic dictum, allowing us to determine what is the real definition of the ger in the CD community. ${ }^{172}$ She attempts, in an extended deliberation, ${ }^{173}$ to find a solution for the association of the ger in the CD community and the opposite viewpoint in 4Q174 (4QFlor)

170 Berthelot, "La Notion," at 174 does not declare this explicitly, but at 175 she explicitly denotes אח as Israelites, stating: "Thus, the ger though being different from the

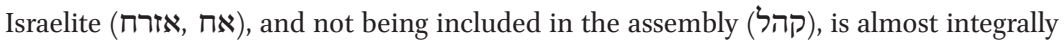
associated in the life of the 'sons of Israel."

171 Ibid., 192. Agnethe Siquans, "Foreignness and Poverty in the Book of Ruth: A Legal Way for a Poor Foreign Woman to Be Integrated into Israel," JBL 128/3 (2009) 443-452, at 446-7 writes that Ruth could not be called a גר she would expect, because "in Biblical Hebrew the term גר exists only in a masculine noun," and therefore a foreign woman cannot live on her own in Israel, as she does not enjoy the same legal status as a man." I have doubts about this statement. The term ger refers to a "resident alien," as Shaye J.D. Cohen writes in "Conversion to Judaism in Historical Perspective: From Biblical Israel to Postbiblical Judaism," Conservative Judaism 36 (4) (1983), 31-45 at 33; namely, someone living in Israel for an extended period, like the Israelites who lived for centuries in Egypt, and who are called gerim in Exod 22:20, 23:9 and in other occurrences. Ruth, however, was a newcomer and could not be called by that name. The absence of the term ger for a female is due to the circumstances. A foreign woman immigrating into Israel as the wife of a foreign man shared her husband's status, and equally occurred if she married an Israelite, because women had no separate legal status. Cohen, "Conversion," at 34 states: "By marrying Israelite men, foreign women would automatically adopt the clan, tribe, nation, and consequently religion of their husbands." See an extended analysis of this issue on p. 321 .

172 Ibid., 192.

173 Ibid., 195-211. 
1-2i, 21:3-5), but finally she admits: "La contradiction avec CD demeure," "the contradiction [of 4Q174, which she calls 4QMidrEschat] with CD remains."174

García Martínez notes the problems of the term in CD and in Scripture, whereas in rabbinic literature "it has a completely different meaning."175 In contrast to Berthelot, García perceives the biblical "brother" and ger as clearly distinct entities. ${ }^{176} \mathrm{He}$ further writes that "the גר belong to the "people" (עם), although not to the "assembly" (קהל). I am not sure that the term קהל indicates a more ultimate communion with the people than the term עy 177 On the other hand, I doubt whether the term עדה, used in Scripture for the description of the Israelite community and for the conveyance of commands (and often in association with the term קהל, indicating their equivalence) expresses a lesser affiliation with the Israelite people than the term קהל. In Exod 12:19, the ger and the ezrakh are components of the Eda: "And anyone, מעדת ישראל בגר ובאזרח הארץ from the community of Israel, whether foreigner or native-born"; this indicates that both groups are elements of the community of Israel. Similarly the phrase: "כל העדה The entire assembly כגר כאזרח whether an alien or native born" (Lev 24:16) plainly implies that both are elements of the כל :assembly. קהל עדת ישראל and in Lev 4:13.179

174 Ibid., 211.

175 Florentino García Martínez, "Invented Memory: The 'Other' in the Dead Sea Scrolls," in Qumranica Minora II, Thematic Studies on the Dead Sea Scrolls (ed. Eibert J.C. Tigchelaar; Leiden: Brill, 2007), 187-218 at 202.

176 In Deut 1:16b, we read: "Judge fairly, whether the case is between two Israelites or between an Israelite and ובין גרו a foreigner residing among you." From the text of this verse we may perceive a difference, at least from the linguistic aspect, between the terms brother and ger. On the other hand, it makes no difference in terms of their rights.

177 We see, for example, the equivalence of the two terms קהל ועל כל עם :16:33 and Lev " הקהל יכפר "make atonement for] all the members of the community."

178 These are the interpretations of the NIV and KJV, but I would like to remark that from the linguistic aspect, it is not evident whether the ger is indeed an element of the community, or lies under the same rules as the Israelite. The interpretation is also dependent on the status of the אזרח in these verses, a topic we discuss below. The rabbinic and traditional commentators' writings are not considering this question explicitly, but implicitly one could deduce opposite viewpoints. From the context of Josh 8:33, we could deduce that the copula כגר כאזרח are elements of the people - they participated in the blessingsbut it does not absolutely confirm that it has always the same meaning.

179 We encounter in b. Qidd. 73a a dispute between two rabbis whether a ger may marry a female mamzer; the rabbi who believes that the ger is included in the 'קהל ה prohibits it (Deut 23:3) and the other who permits it maintains that he is not included in the assembly of the Lord. 
García further states that the גר is also mentioned in opposition to the אזרח belongs to the "sons of Israel," the גר גזרח does not. It is not perfectly clear to me who is meant by the אזרח: does it intend the Israelites, or the non-Israelites that lived in Israel since time immemorial, as the LXX term $\alpha$ vं $\chi \theta \omega \nu$ "indigenous" is presumed to intend? We must consider that Scripture is supposed to have been written in the desert, before the entrance of the Israelites into the Promised Land, which was perhaps populated by other peoples in addition to the Canaanites. If indeed the אזרח intends the Israelites, as one may understand from García's exposition and the statement that they are בני ישראל, that is, ethnic Israelites, the ger, in contradistinction, according to García, cannot cross the ethnic barrier and "can never become an element of "180 I have however some problems with the identification of the term אזרח in Scripture. Tg. Onq. translates יצזרז in Num 15:13 as "planted," that is, someone planted in the land, ${ }^{181}$ a denomination that seems odd referring to Israelites in a law whose inception would be after entering the land (Num 15:2). It seems rather to relate to the autochthonous inhabitants of the land. ${ }^{182}$ Num 15 distinguishes between the ezrakh and the ger, citing them in separate vv. 13 and 14 to communicate that the same rule is valid for both, but it does not state explicitly whether the ezrakh is an Israelite. Tg. Ps. J. adds "except the sons of the nations" to it. Lev 19:34 כאזרח מכם "like a native born from you" (my italics) seems to indicate the ezrakh as an Israelite. Num 9:14, however, "the same regulations for you and the ger and the ezrakh," seems to indicate that neither are an element of the people; they are only compared with respect to the law. והיה כאזרח הארץ "[the ger] will be like one born in the land" in Exod 12:48 seems to perceive the ezrakh as an Israelite, but verse 49: לאזרח ולגר הגר בתוככם "[The same law applies] both to the native-born and to the foreigner residing among you," is ambiguous; it depends whether the qualification "residing among you" refers to both the ezrakh and the ger, and thus, the ezrakh is not perceived as an Israelite, or only to the ger, in which case the ezrakh is perceived an Israelite. Mek. R. Simon Ch. 12, v. 48 interprets ezrakh here as a converted foreigner after circumcision, ritual bath and offering, and hence an element of the people. Tg.Onq. translates it as native-born, a vague literal interpretation, whereas Lekah Tov perceives

\footnotetext{
180 Ibid., 203.

181 The root of the term is נצב "to plant," as Tg. Onq. translates the term עיטב "he planted" as ונצב in Gen 2:8.

182 The Hebrew אזרח has the same affinity with "plant," as we see from its use in Ps 37:35: "flourishing like a green tree in its native soil," or in Amos 9:15: "I will plant Israel in their own land."
} 
it as referring to an Israelite. It is not in the scope of this study to offer a solution to these questions; I wish only to draw the attention to the complexity of scriptural terms that compel us to be careful before making conclusions about the semantic range of a particular term. These terms have many meanings, as I have demonstrated in this chapter regarding a number of them.

Before approaching the more complicated topic of the many meanings of the term in Scripture, I will mention in short the Qumranic and the rabbinic understanding of the term As it seems from the text of $1 \mathrm{Q}_{2} 8^{\mathrm{a}}\left({ }_{1} \mathrm{QS}^{\mathrm{a}}\right)$ I:6-7, the term relates to Israelites. One can derive the same conclusion from $4 \mathrm{Q}_{423}\left(4 \mathrm{Q}\right.$ Instrg $\left.^{\mathrm{g}}\right)$ 5:4: gerim and ezrakhim are different entities, but both are part of the community, and will enjoy the same privileges, although the ger is classified lower in the community's hierarchy. $4 \mathrm{Q}_{3} 65\left(4 \mathrm{QRP}^{\mathrm{c}}\right) 22 \mathrm{a}-\mathrm{b}$ and $23: 1$ repeat the biblical verses Lev 18:26 and 23:42. Lev 18:26 is ambiguous, as said above about the similar text of Exod 12:49, but 23:42, as I understand, explicitly perceives ezrakh as Israelite. It is the only command to live in the booths, and is followed by its justification, connecting their future generation to their past, the exodus from Egypt.

The rabbinic view is identical with that of Qumran, apprehending the term כל האזרח [ as the children of Israel. We read in b. Sukkah 27b: "[It is written בישראל 'all native-born Israelites are to live in booths' (Lev 23:42), that comes to teach us that all Israelites may sit in one Sukkah." Other rabbinic dicta confirm this rule; the succeeding rabbinic midrash decrees that an alien converted in the middle of the Booths holiday changes his status; he becomes an ezrakh, and is obligated immediately to sit in the booths. Mek. Bo Mass. D'Piskha parsha 15, relying on the phrase והיה כאזרח הארץ, states that an alien converted between the First and Second Passover must perform the Second, because he is perceived to be an ezrakh by his conversion. ${ }^{183}$

The term in biblical literature has many meanings, just like the other terms discussed earlier in the study, and I believe that there is no way to reconcile between them, except admitting that they represent different stages and types of aliens' acculturation in Israel. The rule that you may give לגר a dead animal to eat (Deut 14:21) must relate to a foreigner who resides in the land, but

183 Although there is some dispute in b. Pesah. 93a about the convert's obligation to perform the Second Passover, it does not affect our statement. The dispute refers to a legalistic principle about the character of the Second Passover, namely whether it is an atonement for the failure to make the First, and since the convert was not obligated to make the First, he is not obligated to make the Second, or whether on the other hand it is a substitution for the First, so that he is obligated to perform it. Both rabbis agree that a convert becomes an ezrakh, a full-fledged Israelite. 
who has not accepted fulfilling all the precepts commanded for the Israelites. He is only obligated, as I understand it, to fulfill mainly those precepts who have an effect on public life, such as keeping the Sabbath, avoiding idolatry, and not consuming blood, which has a special, probably ancient occult significance. ${ }^{184}$ On the other hand, atonement of the foreigners ולגר for involuntary transgressions in Num 15:26 seems to relate to the ger, who has joined the people of Israel. In contrast, the ger of Deut 14:21 does not need atonement for involuntary transgressions, since he is not commanded to fulfill all precepts. I also think ${ }^{185}$ that the obligation to wash oneself and one's clothes after eating polluted food, as in the admonition to wash one's clothes after eating a carcass, otherwise one shall $\sin \left(\operatorname{Lev} 17: 15^{-16}\right),{ }^{186}$ does not relate to an alien who has not joined the people of Israel and its laws. It refers, rather, to a ger, who has taken upon him the fulfillment of all precepts like an Israelite, and must wash himself and his clothes before entering a sanctuary. ${ }^{187}$ There is no transgression to remain polluted for a longer period, if one does not enter a sanctuary in a polluted status.

The extreme difference between the identity and character of the ger in biblical literature seems to me to be most pronounced at the comparison of his status in Deut 29:9-12 and 31:12, and also in Deut 28:43. We read in Deut 29:9-12 וגרך אשר בקרב מחניך (10-13 in KJV), at the making of the Covenant in which the "foreigners living in your camps" participate together with the entire community. We encounter in Deut 31:12 a similar inclusion of the ger in the community, at the decree of the Assembly to "listen and learn to fear the LORD your God and follow carefully all the words of this law."

הגר" : The foreigners who reside among you will rise above you higher and higher, but you will sink lower and lower." There is no way to reconcile between these two portrayals of the ger. Since both appear in Deuteronomy, one cannot even presume a diachronic difference. We must admit that the ger in Deut 29 and 31 refer to fully integrated foreigners, who joined the people

\footnotetext{
184 We observe in Lev 10-12 the strong admonition against eating blood, its motive, and God's "personal" involvement in the punishment of the transgressor.

185 Berthelot "La Notion," 174 writes: "whereas Lev 17:15 forbids the ezrakh and the ger to eat meat of a torn animal, Deut 14:21 permits the ger to eat it." In fact, Lev 17:15 does not prohibit eating such meat; it only decrees that the Israelite and the ger must cleanse themselves after eating it. I therefore propose this statement with some reservations.

186 The literal translation is "he will bear his sin," and Sifre Num piska 1 states the punishment of Karet for failing to wash oneself and punishment of lashes for his clothes. The LXX translates it: $\lambda \eta \dot{\mu} \mu \varepsilon \tau \alpha \mathrm{\alpha} \alpha \dot{\nu} \dot{\mu} \eta \mu \alpha$ "bearing his lawlessness."

187 Sifra Lev. 17 on this verse confirms it.
} 
of Israel, and as we can deduce from Deut 23:4-9 they include members of all other nations not enumerated there who can join the קהל ה' "enter the Assembly of the LORD." They may still be called gerim, because as is clear from the Pentateuch they did not have land, a determinant factor for keeping one's name, as we have seen at the narrative of Zelophehad's daughters (Num 27 and 36 ). We can observe that a person's shame and tarnished reputation was remembered for a long period, as we read in Deut 25:10 regarding the man who refused to accomplish his levirate duty. A similar deprecating sobriquet may have plausibly been attached to a "landless man."

On the other hand, there were non-Israelites, probably Canaanites, who were not annihilated as Deut 7 commands (1 Kgs 9:20-21) but remained living among the Israelites, as we see from the places that were not conquered by the various tribes, enumerated in Judg 1 . They were not treated well by the Israelites: the Gibeonites were used as woodcutters and water carriers (Josh 9), and the gerim were employed as forced labourers by David and Solomon (1 Chr 22:2 and 2 Chr 2:16). ${ }^{188}$ These foreigners may have been the gerim of Deut 28 , but at any rate there were alien peoples living among the Israelites, who were happy when the Israelites, who may have treated them badly, were defeated.

I postulate, therefore, that by analogy with these irreconcilable references from Deuteronomy we ought to consider the two outright dicta in Qumran literature as referring to two utterly different types of gerim. Those of the CD XIV:3 -6 ordinance ${ }^{189}$ refer to those gerim who joined the Jewish people and undertook the obligations to live according to the Law of the Sons of Zadok. They were called גר נלוה 4Q169 (4QpNah) 3-4ii:9,190 and were fully fledged

188 The traditional commentators, presuming that all the members of the seven Canaanite peoples were annihilated according to the command in Deut 7 and the narratives in Josh 9:7 and 24, allege that they were the descendants of the Gibeonites, an assumption that would conflict with the narrative of 2 Sam 21 that most of them were killed by Saul. I am not claiming that these narratives, and the numbers of the forced labourers in 2 Chr 2:16 called gerim, are authentic, but they may contain a kernel of truth. 1 Kgs 9:20-21 affirms that Solomon's forced labourers were the Canaanite remnants whom the Israelites could not exterminate. Sara Japhet, in The Ideology of the Book of Chronicles and its Place in Biblical Thought (translated from the Hebrew by Anna Barber; Winona Lake, IN: Eerdmans, 2009) postulates that all these references should be perceived as complementary, relating to the same group of persons. These quotations demonstrate the wide array of usages of the concept gerim in Scripture.

189 See p. 357 .

190 Its source is probably Isa 56:3: "Let no foreigner הנלוה אל ה' who is bound to the LORD say "The LORD will surely exclude me from his people.' " We observe the use of biblical 
members of their community, with the right to ask questions, that is, participate in the debates: a privilege which women, children, and deformed persons did not have. The other gerim, mentioned in 4Q174 (4QFlor), never joined the Israelite people or adopted their belief and customs, and thus did not enter the Israelite community and could never enter the Temple. The uncircumבו גר בן נכר is compared to the a sobriquet with a vicious connotation in כל בן נכר ערל לב וערל בשר:Qumran writings; its source seems to be Ezek 44:9 "No foreigner uncircumcised in heart and flesh is to enter my sanctuary, not בן even the foreigners who live among the Israelites." Its parallel in 4 Q174 is "the alien and the uncircumcised Gentile living in the land of Israel," who must never enter the Temple. I would hesitate to suggest that the Torahcentered community of Qumran would prevent the entrance of foreigners into the "Assembly of the LORD," in contradiction to the implicit biblical rule that members of other nations than those specified in the prohibition may join the assembly, subject to acknowledging the Jewish God and fulfilling his commands. ${ }^{191}$ Such an assumption would be contrary to the audience's horizon of expectation, a condition for the reception of a thesis by its audience/readers, as defined by Robert Kugler. ${ }^{192}$ As we have seen (p. 357), the author of 4Q174 employs biblical language from Deuteronomy and an allusion to Ezekiel. ${ }^{193}$

\subsection{Conclusion}

In bringing this chapter to a close, however, I would like to propose another conceivable solution to the apparent contradiction between the Qumranic dicta regarding the attitude towards the ger. We encounter in $m$. Yad.4:4 the rabbinic decision to permit the conversion of Ammonites and Moabites, on the basis that there were no more pure Ammonites and Moabites, since Sennacherib

language in Qumran literature to emphasize the biblical source as their foundation of halakhot and doctrines.

191 In addition to the dicta cited above that explicitly acknowledge the acceptance of the converted ger as a member of the Qumran community, we encounter many implicit texts pointing in the same direction, for example in 1QS II:18-23, 1Q33 (1QMilhamah) VII:3-6, ${ }_{11 Q 19}$ (11QTemple ${ }^{a}$ XXI:4-7 and 1QS VI:7-9. Since we know that Qumran accepted proselytes, and they are not excluded from participating in the above-cited occurrences, it is obvious that they participated in them, like all regular members of the Yahad.

192 Robert A. Kugler, "Hearing 4Q225: A Case Study in Reconstructing the Religious Imagination of the Qumran Community," DSD 10/1 (2003) 81-103, at 89.

193 We read in Ezekiel 30:12: "By the hand of foreigners I will lay waste the land and everything in it." 
had mixed the nations by transferring conquered peoples to other lands in which there remained some people from the previous nationalities. ${ }^{194}$ Thus, they intermarried and were mixed. One cannot exclude the possibility that, as in many other instances, Qumran scholars did not acknowledge the Rabbis' halakhah, especially in this case. Hence, it is possible that Qumran disputed this early rabbinic or already Pharisaic halakhah, since the Patriarch Rabban Gamaliel also disputed it; thus, 4Q174 refers to the conversion of Ammonites and Moabites. The rabbis involved in the dispute were living at the time of the Temple's destruction, that is, before and after the conquest of Jerusalem, and hence such a circumstance could be plausible from the aspect of the period.

I hope to have offered a reasonable explanation for the serious apparent differences between the two Qumranic dicta regarding their attitude towards the "converted" alien, the biblical ger, while at the same time effectively disputing the claim that Qumran scholars, as in Ezra's intermarriage prohibition, prohibited any sexual relationship between Israelites and Gentiles because of the forbidden admixture of Israelite holy seed with alien profane seed, as Hayes claims. Such a concept was extraneous to Ezra and the ancient Israelites, and I have attempted to demonstrate that an attentive reading of the text without predispositions implies Ezra's fear of acculturation with the surrounding nations by socializing with them. Such circumstances would ultimately lead to the apostasy of the tiny, impoverished Jewish minority through the culture and religion of the wealthy pagan majority.

\section{8 טמאז in Scripture, Qumran and Rabbinic Literature, and Scholarship}

This appendix will consider the meanings and applications of the term טמא in Scripture, as well as its interpretation and use in scholarship, demonstrating its various connotations. We encounter common ritual impurities, such as contact with a human ${ }^{195}$ or animal carcass, in Num 19:14-16, Lev 11:25, and many other occurrences. There are, however, different types and degrees of impurities, depending on the manner of becoming impure, its duration, and the

194 See 2 Kgs 17:24-41 and 18:11. In 2 Chr 30 we observe that King Hezekiah sent messengers to the Israelites that lived in the land after the displacement of the Israelites by Sennacherib.

195 In the case of a human carcass the concept of contact includes not only physical contact but also being in the same room/tent. Contact with animal carcasses and with other sources of impurities generated different complex rules, but it is not in the scope of this broad schematic list to deliberate about these intricate details. 
procedure for cleansing; for example, contact with a human carcass requires cleansing by sprinkling ashes of the Red Heifer, diluted with water. All those rendered impure are prohibited to enter a holy place or touch holy substances during the period of their impurity.

Similar to these impurities, there are the impurities of the menstruate woman (Lev 15:19), the woman in childbirth (Lev 12:2), the man after an involuntary discharge (Lev 15:16), and both man and woman after sexual intercourse (Lev 15:18). There are different durations of impurity and procedures for cleansing. Again, entering a holy place and touching holy substances are forbidden during the period of impurity. The woman who has given birth is required to bring a special offering at her cleansing procedure.

Then we have the impurity of the diseased discharges of men and women (Lev 15:2-15 and 25-33), and the impurity of the leper (Lev 13:2-46). Both are required to bring offerings at their cleansing procedures, although these offerings and procedures are different to each other in all aspects. Both are prohibited to enter a holy place or touch holy substances during their impurity, but the leper is banned from the Israelite camp, must stay in isolation, and must warn the people of his "impure" status. Impurity radiates upon the pure person or substances through physical contact, except that the leper, as the human carcass also radiates impurity upon what is present under the same roof. ${ }^{196}$

We also encounter the use of the term טמא for mildew in cloth and leather (Lev 13:47-59) and in a building (Lev 14:34-53). Although these items are declared impure, contact with them has no effect on persons or substances. There is no provision for a cleansing procedure; the elimination of the mildew ends the impurity of the materials, or else they are destroyed if the mildew persists.

The above impurities, despite their differences, can be classified as "concrete" impurities, in the sense of being the consequence of some sort of physical occurrence, either by their own action, by an action done to them, or through what has happened to them, as for example sickness. The termination of the impurity occurs at predetermined times or at healing, without or with special procedures, such as the sprinkling of the Red Heifer solution, special offerings after the healing of diseases, or a specific cleansing procedure for the healed leper.

We come now to the more complex metaphorical uses of the term טמא for a great variety of applications, beginning with the simple "impurity" of animals

196 In the case of the leper this is a matter of rabbinic interpretation, being not clearly evident from the scriptural text. 
in the sense that one may not consume them (Lev 11:4-7). Touching them while alive does not transmit impurity, only their carcasses have this effect (Lev 11:27-38), but the same applies to the carcasses of pure animals, those which are permitted for consumption (Lev 11:39-40). Thus, we observe already a difference in the essence of the טמא concept for animals, but we encounter a much greater distinction with creeping or crawling creatures, an impurity with far-reaching consequences, as we read in Lev 11:43-44. In contrast to the other unclean animals, we observe severe consequences of consuming these creatures; they have an impact on the souls of Israelites, making them detestable/abominable/disgusting (according to the different translations NIV, KJV and LXX) and impure, and infringing on their holiness. ${ }^{197}$ We have three quotations of the term טמא in the two verses, out of which the NIV translated two as "defile" and one as "unclean." The different translations indicate the translators' interpretations as founded on previously acquired knowledge or preconception, pointing to the complexity of the issue of interpreting a generic biblical term into distinct English terms (or indeed distinct terms of other languages), according to interpreters' choices and preferences.

Lev 14:40b: "and throw them into ממקום טמא an unclean place outside the city" raises other questions. Does the term טמא מקום here intend a "ritually impure site" or just a soiled place outside the city, to which all kinds of the city's refuse and garbage are removed? Further, if it is a "ritually impure" place, we don't know how an open place outside the city can become "impure": there is no such rule in Scripture. Rashi is aware of the problem, and postulates that intends a place where "pure" matter is not brought, since it would become impure as long as the "impure" stones remain deposited there. I am not, however, convinced that this is the correct interpretation in this case. It is the only place in Scripture using the phrase מקום טמא. We encounter the phrase מחוץ למחנה "outside the camp" without any qualification, and in some instances with the attribute אל מקום טהור "a clean place." I also have not found anywhere that the ground becomes impure when an impure substance is placed upon it.

197 Whether theses specific consequences relate to all "impure animals and creatures" or only to those creatures quoted in vv. 41-42 is debatable. See Martin Noth, Leviticus: A Commentary (transl. from German by J.E. Anderson; London: scm Press, 1965) and Karl Elliger, Leviticus (Tübingen: Mohr (Siebeck), 1966) 147-8 and 154-5. From Lev 20:25-26 it seems that the same consequences apply to all impure animals and creatures. These verses contain the identical concepts of שמא, שקץ and the holiness of Israel; they add the concept of separation. Just as God separated the Israelites from other peoples, choosing them as his people, he separated the pure and impure animals and creatures. 
The state of impurity of foreign lands is a late rule, instituted about the middle of the Second Century все (b. Shabb. 14b). I would hypothesize that in our case, it means just a dirty place, outside the town, to which all refuse and garbage are removed. Hence, we have another meaning of the term טמא. I would like to draw attention to a difference between the phrases במקום קדש "holy place" and במקום טהור "NIV adds ceremonially] clean place" in Lev 10:13 and 14. According to the rabbinic interpretation, which seems to be correct in the context, במקום קדש relates to the Temple precinct, and במקום טהור refers to the city of Jerusalem.

Another similar odd meaning of the term טמא is found in Josh 22:19, at Phinehas' speech to the tribes that chose the land east of the Jordan as their inheritance. We read there: "But now, if the land of your possession is טמאה unclean, pass over into the LoRD's land." The NIV interprets the term טמא as "defiled," the KJV and the RSV as "unclean," but the LXx, probably since these habitual interpretations make no sense at all in the context, interprets it as

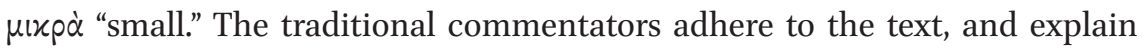
its meaning as intending not holy enough for God to build the Temple there, with various nuances. We observe the many meanings of these terms and their opposites, the subject of our current inquiry.

We come now to a number of abstract usages of the term טמא, whose real meanings and consequences are not divulged. I refer first to the use of the term in Gen 34:5, 13 and 27, all three times inserted by the author/redactor of the narrative rather than being assertions of Jacob and his sons, and translated as "defiled," but without any indication of a motive. The manner of Shechem's sexual intercourse with Dinah, namely seducing or raping her, is not clearly indicated. The text of Gen 34:2 reads ויענה "violated her" in the NIV, "defiled her" in the KJV and "humbled her" in the Rsv, following the LXX translation $\tau \alpha \pi \varepsilon i v o ́ \omega$ "to humble." The same term ענה is used in Deut 22:29 regarding a rape case, according to rabbinic interpretation ( $m$. Ket. 3:4 and b. Ket. 39b), and a seducing event by the Temple Scroll ${ }_{11}{ }_{19}$ (11QTemplea) LXVI:8-11. Here, the LXX and the NIV are consistent: the first translates the term ענה "humbled" and the second "violated." On the other hand, the KJV translates here the term "humbled," and the Rsv "violated"; it confirms again the complexity of adapting the translations of the term to our modern preconception of how it should be interpreted according to the context. However we interpret the term ענה in Deut 22:29, either as "humbled" or "violated," it does not indicate the essence of the term טמא as used by the author/redactor of Gen 34, and does not justify its usual translations as "defiling/making impure/profaning." Although the sexual intercourse of Shechem with Dinah is portrayed by the term ענה in Gen 34, טמא exactly as in Deut 22:29 and hence relating to an identical event, the term 
is not used in the biblical text of Deut 22:28-29, and its significance in Gen 34 remains elusive. ${ }^{198}$

We can now approach the scrutiny of another biblical text relating to sexual delinquencies, that of adulterous intercourse (Lev 18:20) associated with the phrase לטמאה בה interpreted as "to defile yourself" by the LXX and the other translators. It would seem that this interpretation was preferred because there is no mention anywhere what type of "impurity" the adulterous man bears; but neither does the interpretation "defile" divulge in what his defilement consists. The term נטמאה in Num 5:13-14 regarding the suspected unfaithful wife is

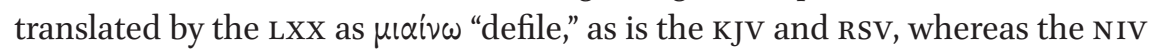
translates it as "impure." Further, it appears from the grammatical structure of the phrase לטמאה בה that the defiling applies only to the man, not to the woman, his partner in the misdeed. The complexity of interpretation of the term טמא is again evident.

We find a similar oddity, the distinction between man and woman, at the discussion of bestiality in Lev 18:23; the man's action is portrayed: לטמאה "to make yourself unclean with it," but the woman's identical act is portrayed as תבל "perversion." Capital punishment is equally imposed on the adulterous woman as upon the man (Lev 20:10), and the punishment for bestial intercourse applies to man and woman alike (Exod 22:18); hence, we are left unaware what the distinct terminology indicates, and whether different consequences are associated with their specific nomenclature. A similar puzzle concerns the meaning of other terms with an affinity to sexual issues, used in Scripture and deliberated upon in this study, such as: זרע ,טמא, שהור, תועבה משע "detestable" (Lev 20:13) and woman's bestiality intercourse תבל קבל "perversion" (Lev18:23), but the transgression of both is identically punished by execution. On the other hand, intercourse with one's sister is called חסד, ${ }^{200}$ and imposes the karet punishment (Lev 20:17), seemingly a lighter penalty.

198 The assumption of some scholars that sexual contact between holy Israelites and unholy Gentiles profanes/defiles the seed/blood refers exclusively to the allegation that the Jubilees author and/or Qumran scholars interpreted it in such a way; all agree that Scripture does not indicate such a theory.

199 I do not perceive the term מעל as related to sexual transgressions. The phrase ומעלה בשטר

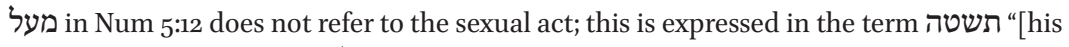
wife] goes astray." The term מעל indicates she was "unfaithful" to her husband as in similar instances, discussed in section 8.4.2 pp. 328-330.

200 In Hebrew the term חסד means "kindness"; in Aramaic it also means "shame," and that is how translators and commentators translate it here and in Prov 25:10. 
We can now return to our main question posited above regarding the practical meaning of defilement, as interpreted for the adulterous or bestialitypractising man, and the absence of the same status or castigation of the woman for the identical transgressions and punishment. I would suggest that the "impurity/defilement" of the term לטמאה בה is intrinsically associated with the succeeding verses linking them with the nations who defiled the land that then vomited them out for their wicked deeds; the term טמא appears five times in the succeeding seven verses ( $\operatorname{Lev} 18: 24-30$ ). That solution seems logical to me in the context, and demonstrates the significance of the term טמא in this occurrence, as intended by the author, even though its exact meaning remains undefined.

Lev 18:24-25 concludes a list of other sexual transgressions with the term טמא used for both the portrayal of the status of the active sinners and the abstract status of the land, translated by the term "defile" by the NIV, KJV and LXX. Num 35:33-34, referring to the sin of shedding blood, uses two parallel terms, טמא and טומאה and The removal of the land's "defiled" status of the atonement of its enigmatic sin seems to be possible solely by the killing of the perpetrator, in this case the murderer. ${ }^{201}$ The enigma concerning how actions or inactions by the people טמא "pollute/make impure/defile" the land arises again in a number of places: in Lev 19:31 at the prohibition of turning to mediums and spirits; in Ezek 20:18 where idols "defile" the land; and in 20:26a with the enigmatic assertion "let them become defiled through their gifts." The phrase טמא שפתים in Isa 6:5 and 52:1 is translated by the LXX as $\dot{\alpha} x \dot{x} \theta$ aptos "unclean," which the NIV, KJV and RSV follow, except that the NIV translates the latter instance as "defiled."

We come now to two peculiar uses of the term טמא in Deut 21:23, translated

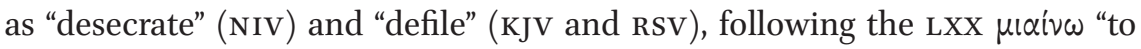
defile" the land by refraining to bury the hanged man in it on the same day. This constitutes an exception, since the term טמא as discussed until now was used for doing something or being exposed to something done by others, but

201 Jonathan Klawans, Impurity and Sin in Ancient Judaism (New York: Oxford University Press, 2000) 26 ff., postulating a distinction between ritual and moral impurities, states: "the moral impurity leads to a long-lasting, if not permanent, degradation of the sinner and, eventually the land of Israel." I will discuss his theory later in this appendix, but this attribute is not appropriate for all types of the alleged "moral impurities." We observe, for example, that in our case, concerning the murderer, the removal of the land's "impurity" can be swift, by the refusal to take pecuniary compensation for the death of a person, and execution of the perpetrator's prescribed punishment. The prompt removal of this type of "impurity" demonstrates the key deficiency of bundling together different wicked acts under one category. 
never for the failure of others to do something, as in this case. Again we are not informed about the essence of this type of טומאה, its repercussions and removal; is the land cleansed by burying the man the next day, or is another procedure necessary? Another enigmatic use of the term appears in Deut 24:4 at the prohibition of the divorcée to return to her previous husband after having been married to another man, and thus הטמאה "defiled"; and would be תועבה "detestable in the eyes of the LoRD." Traditional commentators and modern scholars attempted to introduce some sense into this obscure rule, but the meaning of the term הטמאה interpreted as "defiled" by the LXX, NIV, KJV and RSv, namely, what the divorcée had done or to what type of defilement had she been subjected in order to generate, as a single person, a sin upon the inherited land, remains elusive. Unlike other transgressions of sexual delinquencies, such an infraction would not provoke "defilement" of the land or the potential to be driven out of it; the emphasis on its bringing sin upon the land without indicating the precise consequences. ${ }^{202}$

Klawans ${ }^{203}$ attempts to postulate a solution for the seemingly odd uses of the term טמא, a terminology inappropriate for example to the portrayal of an adulterous sexual intercourse or to the impurity of the land because of the wicked practices of its inhabitants. He postulates perceiving a "ritual impurity" for the common impurities and a concept of "moral impurity" for the others. The compound expression "moral impurity," however, is a fusion of the ancient mystical concept of "impurity" with the modern concept of morality/ethics. There is no such concept in Scripture; all those rules that seem to us as socially motivated, and hence founded on ethical principle, are presented in Scripture strictly as divine decrees, their transgressions being punishable directly by God or by humans according to divinely established, rigid and immutable rules. Human courts must decide whether the accused is guilty or not, but cannot alter the divinely prescribed verdict for the delinquency or forgive the criminal altogether. In cases in which humans cannot know whether a person

202 David Instone Brewer, "Deuteronomy 24:1-4 and the Origin of the Jewish Divorce Certificate," JJS 59/2 (1998) 230-243, at 231-235 offers a record of various scholarly hypotheses proposed to explain this apparently odd rule. He seems to endorse Westbrook's complex theory in "Prohibition of Restoration of Marriage in Deuteronomy 24:1-4," in S. Japhet, Studies in the Bible 1986: Scripta Hierosolymytana 31 (Jerusalem: Magnes, 1986) $387-405$, but I do not see eye to eye with them on this justification. While I agree that we should attempt to reveal the logical root of ancient bizarre rules and customs, we must sometimes admit our inability to disclose their rationale, which in some instances may have been already obscure to the composers of the ancient document. I would suggest considering this rule of prohibiting remarriage with a divorced wife as one such case.

203 Klawans, Impurity and $\operatorname{Sin} 26 \mathrm{ff}$. 
performed a wicked act, as for example indicated in Lev 19:14 not to curse the deaf or to put a stumbling block before the blind, the seemingly superfluous phrase "fear your God: I am the LORD" at its end and at similar decrees in that chapter indicates that God himself, who knows whether these evil deeds were performed (the concerned persons being unaware of it), will punish the transgressor. Similarly, the perpetrator of an ethical offence, according to our viewpoint, which cannot be prosecuted by a human court, will be punished by God "personally," as for example we read in Exod 22:21-22 (22-24 in KJV).

Moreover, Klawans' theory does not solve the impasse; whereas the classification of animals as טהר (Lev 11:47) can be codified in terms of ritual impurity, the theory does not explain what type of impurity pollutes the earth because of the failure to bury a hanged man on the same day (Deut 21:23). The earth cannot be classified as either ritually or as morally impure. Neither can it explain the type of טומאה "impurity" in similar circumstances in which the land becomes טמא. Consequently, the generic label "moral impurity" cannot be attached to the term טמא in all occurrences that cannot be classified as "ritual impurities"; doing so seems to me unwarranted, and also leading to erroneous conclusions. I therefore postulate that we should conceptually detach the term טמא in these instances from any relationship with the notion of purity and impurity.

The use of the term טמא in these occurrences in which the concept of ritual impurity is not appropriate is due to the want of other suitable terms in the biblical language, but need not stimulate the devising of modern concepts of "moral impurity." The biblical concept טמא is difficult to explain to a modern person; it is beyond perceptible reality and our modern way of thought, and its undifferentiated use in Scripture at different instances makes it even more elusive to our tangible perception.

How can we hope to understand why a person rendered ritually impure as a result of some contact with a corpse (even only being in the same room) must be sprinkled with a solution of water mixed with the ashes of the Red Heifer, while another ritually impure person, for instance one with a diseased discharge, does not require it? Further, why are the priest who burns the purifying Red Heifer and the man who collects its ashes impure for one day? The Zoroastrian religion, for example, possesses a division between good and bad animals, associated respectively with the good god Ahura Mazda and the evil god Ahriman. Likewise it acknowledges the concept of an abstract type of טומאה, and its removal is a significant element in that religion. In the Indo-Iranian practice of the great purification for the initiation of priests and corpse-bearers, an important part is played by gomez, consecrated urine, 
originally cow's urine. ${ }^{204}$ We must, therefore, accept the biblical terms as not fully comprehensible for modern readers, and avoid imposing our current manner of thought and method of research on ancient writings, particularly regarding esoteric topics.

We have observed the different meanings of the term טמא in Scripture, and its varied interpretations into English terms dependent on the exegesis of the text by the translator/interpreter. Some English terms are perfectly interchangeable in some instances, but not in others. Consider, for example, the correlated terms "defile" and "desecrate." In the rule to bury the hanged man on the same day, the term "defile" the land, chosen by some translators, seems to me more appropriate than "desecrate" chosen by another. For the description of the transgressing of the Sabbath prohibitions or the desecration of God's name, both expressed in Hebrew by the term the term "desecrate" seems to better me than "defile," whereas for the son of a priest from a prohibited marriage, identified in Scripture by the same term חלל, the translation "defile" seems to me more appropriate. The son was never sacred in the first place, being unfit to serve as a priest from his sinful conception, and thus cannot be desecrated. Utmost care must, therefore, be applied to the correct interpretation of the various terms considered in this survey, before drawing philosophi$\mathrm{cal}$ and/or theological deductions from a possible incorrect translation.

We observe similar conceptual variances of the term טמא in Qumran literature. I would suggest dividing them in three categories:

a) concrete ritual impurity, such as contact with human and animal corpses or with specific human discharges and diseases, as well as mildew of cloth and houses;

b) metaphysical impurity, such as ritually pure and impure animals, and abstract impurity of the soul;

c) abstract impurity resulting from i) adultery, ii) defilement of land, Temple, or altar by people's wicked behaviour, iii) the presence of blemished persons who pollute (make impure) Jerusalem.

I would include in group a) occurrences of the term טמא in the following writings:

204 Adapted from the Encyclopedia of Religion (ed. Mircea Eliade; New York: MacMillan Publishing Co., 1987). 
CD IV:18 and V:6;205 X:13; XI:19 and 22; XII:17-18; 1Q28a: XI:3; 4Q265 (4Q Misc Rules) 7:15; 4Q266 (4QDa) 9ii:3; 4Q271 (4QD) 2:11; and many others. In group b) (metaphysical impurity), I would classify CD VI:15; XII:20; 1Qp-Hab VIII:13; 1QS III:5; V:12; VI:20; 4Q177 (4Q Catena A) 7:6; 4Q257 (4Qpap Sc) III (iii, 2a-g):7; 4Q262 (4QS' $)_{3}$; 4Q365 (4Q RPc) 17a-c:4; 4Q383 (4Q apocr Jer A) 6:2; 4Q396 (4QMMTc) IV:10; and others.

In group c) (abstract impurity of land, altar, Temple, and holy spirit), I would place CD IV:18; V:6 ${ }^{206}$ and 11; XX:23; 1QpHab. XII:8; 4Q183 (MidrEschate) 1ii:1; 4Q251 (4QHalakha A) 18:2; 4Q270 (4QD $)$ 2ii:11; 4Q39o (4Q apopcr. Jer Ce) 2i:9; ${ }_{11}{ }_{19}\left(11 Q\right.$ Templea) LI:14, ${ }_{11 Q 19}$ (11Q Temple $\left.{ }^{a}\right)$ LXIV:12; $11 \mathrm{Q} 19$ (11Q Templea ${ }^{\mathrm{a}}$.

We observe that the term טמא in Qumran literature has similar meanings to those of Scripture, and this must be considered when interpreting them; context is the key for a correct understanding of the text.

205 See a discussion in Chapter 6, p. 223, on the consequences of a different interperation of the term טמא in these two verses by me and by Adiel Schremer, "Qumran Polemic on Marital Law: CD 4:20-5:11 and its Social Background," Damascus Document: a Centennial of Discovery; Proceedings of the Third International Symposium of the Orion Center for the Study of the Dead Sea Scrolls and Associated Literature 4-8 February 1998 (eds. Joseph M. Baumgarten et al.; Leiden: Brill, 2000) 147-16o at 149-152. According to my interpretation these two terms should be considered as abstract impurity of the Temple by wicked deeds, as in Lev 20:3, whereas Schremer perceives them as concrete impurity.

206 See antecedent note. 